\title{
Regulation of Neuronal Gene Expression and Survival by Basal NMDA Receptor Activity: A Role for Histone Deacetylase 4
}

\author{
Yelin Chen, ${ }^{1}$ Yuanyuan Wang, ${ }^{1}$ Zora Modrusan, ${ }^{3}$ Morgan Sheng, ${ }^{1}$ and Joshua S. Kaminker ${ }^{1,2}$ \\ Departments of ${ }^{1}$ Neuroscience, ${ }^{2}$ Bioinformatics and Computational Biology, and ${ }^{3}$ Molecular Biology, Genentech Inc., South San Francisco, California 94080
}

Neuronal gene expression is modulated by activity via calcium-permeable receptors such as NMDA receptors (NMDARs). While gene expression changes downstream of evoked NMDAR activity have been well studied, much less is known about gene expression changes that occur under conditions of basal neuronal activity. In mouse dissociated hippocampal neuronal cultures, we found that a broad NMDAR antagonist, AP5, induced robust gene expression changes under basal activity, but subtype-specific antagonists did not. While some of the gene expression changes are also known to be downstream of stimulated NMDAR activity, others appear specific to basal NMDAR activity. The genes altered by AP5 treatment of basal cultures were enriched for pathways related to class IIa histone deacetylases (HDACs), apoptosis, and synapse-related signaling. Specifically, AP5 altered the expression of all three class IIa HDACs that are highly expressed in the brain, HDAC4, HDAC5, and HDAC9, and also induced nuclear accumulation of HDAC4. HDAC4 knockdown abolished a subset of the gene expression changes induced by AP5, and led to neuronal death under long-term tetrodotoxin or AP5 treatment in rat hippocampal organotypic slice cultures. These data suggest that basal, but not evoked, NMDAR activity regulates gene expression in part through HDAC4, and, that HDAC4 has neuroprotective functions under conditions of low NMDAR activity.

Key words: activity-dependent gene expression; apoptosis; HDAC4; NMDA receptor

\section{Introduction}

NMDA receptors (NMDARs) play a fundamental role in many brain processes and are implicated in a variety of nervous system disorders (Paoletti et al., 2013; Zhou and Sheng, 2013). While resting NMDARs are typically inactive due to $\mathrm{Mg}^{2+}$ blockade, neuronal depolarization leads to a reduction of $\mathrm{Mg}^{2+}$ inhibition, enabling NMDAR activation by glutamate. Gene expression changes downstream of NMDAR activation are critical for normal nervous system physiology and are also relevant in pathological situations, such as excitotoxicity (Zhang et al., 2007; Hagenston and Bading, 2011).

NMDAR signaling has generally been studied by using NMDAR agonists or $\mathrm{GABA}_{\mathrm{A}}$ receptor $\left(\mathrm{GABA}_{\mathrm{A}} \mathrm{R}\right)$ antagonists, both of which strongly stimulate NMDARs above their basal level of activity (Sala et al., 2000; Hardingham et al., 2002; Zhang et al., 2007). However, data exist to suggest that NMDARs play a significant role in neuronal function under basal as well as hyperexcited conditions. For example, the inhibition of basal NMDAR

Received Feb. 9, 2014; revised Aug. 26, 2014; accepted Sept. 14, 2014.

Author contributions:Y.C., M.S., Z.M., and J.S.K. designed research; Y.C., Y.W., and Z.M. performed research;Y.C., Y.W., Z.M., and J.S.K. analyzed data; Y.C., M.S., and J.S.K. wrote the paper.

We thank Drs. Baris Bingol, Thomas Sandmann, Felix Yeh, and Meghan Kerrisk Campbell for helpful suggestions and advice during the writing of the manuscript.

The authors are employees of Genentech Inc., a member of the Roche Group.

This article is freely available online through the J Neurosci Author Open Choice option.

Correspondence should be address to either Morgan Sheng or Joshua S. Kaminker, 1 DNA Way, South San Francisco, CA 94080, E-mail: sheng.morgan@gene.com or kaminker.josh@gene.com.

DOI:10.1523/JNEUROSCI.0569-14.2014

Copyright $\odot 2014$ the authors $\quad 0270-6474 / 14 / 3415327-13 \$ 15.00 / 0$ activity rapidly and sustainably potentiates excitatory synaptic strength (Sutton et al., 2006; Autry et al., 2011), possibly underlying the apparent antidepressant effects of NMDAR antagonists (Zarate et al., 2006; Autry et al., 2011). Additionally, basal NMDAR activity is required for $\beta$-Amyloid-induced synaptic deficits (Nakagawa et al., 2004; Shankar et al., 2008; Wei et al., 2010; Jiao and Li, 2011; Kessels et al., 2013), and an NMDAR antagonist, memantine, is used to treat Alzheimer's disease (Reisberg et al., 2003). As the effect of NMDAR activation is highly context dependent (Sala et al., 2000; Hardingham et al., 2002; Liu et al., 2004; Kim et al., 2005; Zhang et al., 2007; Hardingham and Bading, 2010), it is likely that basal NMDAR activity regulates a distinct downstream gene expression program compared with that of stimulated NMDAR activity. However, the exact transcriptional events downstream of basal NMDAR activity remain poorly characterized.

Chromatin modifications by histone deacetylases (HDACs) are known to regulate transcription in neurons (Haberland et al., 2009). Mutations in the ataxia telangiectasia mutated gene in mice result in abnormal nuclear accumulation of HDAC4, abnormal histone acetylation, and cerebellar neurodegeneration (Li et al., 2012). Additionally, the expression of a constitutively nuclear-localized HDAC4 mutant in mice leads to synaptic and learning deficits (Sando et al., 2012). In humans, a variant in HDAC4 causing constitutive nuclear localization has been linked to a rare brachydactyly mental retardation syndrome (Williams et al., 2010). While these data point to an important role for HDAC4 in the brain, its precise function and regulation are unclear. 
Here we show that under conditions of basal activity, treatment of cultured neurons with a broad NMDAR antagonist, AP5, results in large-scale gene expression changes. Similar, but less robust, changes were observed after treatment with subtypeselective antagonists of NMDARs Ro25-6981 (Ro25) or NVPAAM077 (NVP). Only a subset of these gene expression changes was previously known to be regulated by NMDAR signaling, suggesting that NMDAR signaling in basal and hyperactive conditions induces distinct transcriptional programs. We show that basal NMDAR activity regulates the expression of genes enriched in apoptosis-related signaling pathways, and additionally, regulates the expression of all three class IIa HDACs (HDAC4, HDAC5, and HDAC9) that are expressed in the brain (Haberland et al., 2009). Knockdown of HDAC4 attenuated a subset of the AP5induced gene expression changes and also led to neuronal death under long-term tetrodotoxin (TTX) or AP5 treatment. Together, these results suggest that HDAC4 plays an important role in regulating the expression of downstream targets of basal NMDAR signaling, and also highlight that HDAC4 has a neuroprotective role under conditions of low NMDAR activity.

\section{Materials and Methods}

Neuronal cultures and drug treatments. Whole hippocampi were dissected from embryonic day 15 (E15) to E16 C57BL/6 wild-type (WT) or GluN2A knock-out (KO) (Kadotani et al., 1996) mice (either sex) in ice-cold HBSS buffer before they were digested by papain. Cells were seeded at 180,000 cells/well in 12-well plates, and 450,000 cells/well in 6-well plates. Cells were grown in B27 neuron chow, which contains 97 $\mathrm{ml}$ of Neurobasal Medium (catalog \#21103-049, Invitrogen), 2 ml of B27 Supplement (catalog \#17504-044, Invitrogen), $0.5 \mathrm{~mm}$ glutamine, 12.5 $\mu \mathrm{M}$ glutamate, and $100 \mathrm{U} / \mathrm{ml}$ penicillin/streptomycin (catalog \#15141, Invitrogen). Neurons were maintained in a $37^{\circ} \mathrm{C}$ cell culture incubator with $5 \% \mathrm{CO}_{2}$ and fed once a week after plating with $\mathrm{B} 27$ chow without glutamate. NMDA $70 \mu \mathrm{M}$ was applied at $21 \mathrm{~d}$ in vitro (DIV) for $10 \mathrm{~min}$ after a 5 min preincubation of either vehicle, AP5 $100 \mu \mathrm{M}$, NVP 0.1 or 1 $\mu \mathrm{M}$ (Auberson et al., 2002; Neyton and Paoletti, 2006), or Ro25-4891 (Ro25) $1 \mu \mathrm{M}$ (Fischer et al., 1997) in a cell culture incubator.

Western blot. Neurons in 12-well plates were put on ice immediately after drug treatment and rinsed once with ice-cold PBS before they were lysed with $100 \mu \mathrm{l}$ of $1 \times$ Tris-glycine SDS Western sample buffer per well. Lysates were shaken for $10 \mathrm{~min}$ at room temperature, followed by $10 \mathrm{~min}$ of boiling and $10 \mathrm{~min}$ of centrifugation at $140,000 \times \mathrm{g}$. Western blots were then performed using Tris-glycine SDS gels. The following antibodies were used in this study: total Erk1/2 antibody [catalog \#9102 (RRID: AB_823494), Cell Signaling Technology], phospho-Erk1/2 antibody [catalog \#9101 (RRID: AB_331646), Cell Signaling Technology], total PSD-95 antibody [clone K28/43, catalog \#75-028 (RRID: AB_2292909), NeuroMab], Apaf1 antibody [catalog \#8723S (RRID: AB_10829610), Cell Signaling Technology], Bid antibody [catalog \#2003S (RRID: AB_10694562), Cell Signaling Technology], Noxa antibody [catalog \#SC-56169 (RRID: AB_784877), Santa Cruz Biotechnology], Puma antibody [catalog \#7467S (RRID: AB_10829605), Cell Signaling Technology], Casp3 antibody [catalog \#9662S (RRID: AB_10694681), Cell Signaling Technology], $\beta 3$ Tubulin antibody [Cat\# 4466S (RRID: AB_1904176), Cell Signaling Technology], HDAC4 [catalog \#SC-11418 (RRID: AB_2118872), Santa Cruz Biotechnology], and HDAC5 [catalog \#2082 (RRID: AB_2116626), Cell Signaling Technology]. PSD-95 Ser295 phospho-specific antibody was described previously (Kim et al., 2007).

DNA constructs. All cDNAs were expressed using the pCAG vector (chicken $\beta$-actin promoter with CMV enhancer). shRNA constructs were annealed and inserted into the HindIII/BglII sites of pSUPER vector (Brummelkamp et al., 2002; Nelson et al., 2013). The targeted cDNA sequences by shRNAs are as follows: pSUPER HDAC4-shRNA (shH4_1): 5'-GGTCATGCCAATCGCAAAT-3'; pSUPER HDAC4-shRNA_1 (shH4_2): 5'-GCTTCTGAAGCATGTGTTTCT-3'; and pSUPER Luciferase-shRNA (shLuc): 5'-CGTACGCGGAATACTTCGA-3'.
Lentivirus. shH4_1 and control shRNA targeting firefly luciferase were subcloned into the pFHSynGW backbone vector from pSuper with its original H1 promoter. GFP expression was driven by a human Synapsin I promoter in the same pFHSynGW vector (provided by Dr. Carlos Lois, Massachusetts Institute of Technology, Cambridge, MA). Lentiviral particles were produced as described previously (Lois et al., 2002). The viral titer was estimated by serial dilution infections of HEK293 cells. Cultures were infected at DIV 14 and used 6-7 d after infection.

Quantitative RT-PCR. Relative mRNA levels were determined using the QuantiTect SYBR-Green RT-PCR (reverse-transcription-PCR) kit (Qiagen) according to its instructions. Glyceraldehyde 3-phosphate dehydrogenase (GAPDH) was used as an internal control. Primers were purchased from Qiagen. Each RT-PCR was performed in duplicate. Expression levels were normalized to vehicle-treated samples and compared with a hypothetical mean of 1 using a one-sample or two-sample $t$ test, as indicated.

Organotypic hippocampal slice culture, electrophysiology, and neuronal survival assay. Patch-clamp recordings were performed from CA1 pyramidal cells in organotypic hippocampal slice cultures dissected from postnatal day 6 (P6) to P7 Sprague-Dawley rats (of either sex; Kim et al., 2007). DIV3 to DIV6 slices were biolistically transfected using a gene gun (Bio-Rad), and cultures were imaged $3 \mathrm{~d}$ after transfection. Ten milligrams of gold particles (1.6 $\mu \mathrm{m}$ in diameter; Bio-Rad) were coated with $90 \mu \mathrm{g}$ of shRNA plus $10 \mu \mathrm{g}$ of EGFP expression plasmids. Synaptic responses were evoked once every $5 \mathrm{~s}$ with a bipolar stimulus electrode placed in the stratum radiatum. The external recording solution consisted of the following (in mM): $2.5 \mathrm{CaCl}_{2}, 2.5 \mathrm{KCl}, 1.3 \mathrm{MgCl}_{2}, 119 \mathrm{NaCl}$, $26 \mathrm{NaHCO}_{3}, 1 \mathrm{NaH}_{2} \mathrm{PO}_{4}, 11$ glucose, 0.1 picrotoxin (PTX), and 0.001 tetrodotoxin, $\mathrm{pH}$ 7.4. The internal recording solution for the patch electrode consisted of the following (in $\mathrm{mm}$ ): 115 cesium methanesulfonate, $20 \mathrm{CsCl}, 10 \mathrm{HEPES}, 2.5 \mathrm{MgCl}_{2}$, 4 ATP disodium salt, $0.4 \mathrm{GTP}$ trisodium salt, 10 sodium phosphocreatine, and 0.6 EGTA, pH 7.3. mEPSCs were recorded at $-70 \mathrm{mV}$. CA1 pyramidal neurons expressing EGFP from the transfected slices were imaged directly in oxygenated aCSF containing $2.5 \mathrm{mM} \mathrm{CaCl}_{2}$ and $1.3 \mathrm{mM} \mathrm{MgCl}_{2}$ using an Olympus multiphoton system with a water-immersion $40 \times$ objective (numerical aperture, 0.8 ; Olympus). Transfected CA1 pyramidal neurons were counted using fluorescence microscopy once every $12 \mathrm{~h}$ for $4 \mathrm{~d}$ after treatment with vehicle, AP5, or TTX. Two-way ANOVA was used to compare shH4_1- or shH4_2-transfected neurons to shLuc-transfected neurons.

Expression analysis. DIV 21 dissociated mouse hippocampal neurons in six-well plates were treated with vehicle, $100 \mu \mathrm{M}$ AP5, $0.1 \mu \mathrm{M}$ NVPAAM077, or $1 \mu \mathrm{M}$ Ro25-4891 for $6 \mathrm{~h}$ in a cell culture incubator. Total RNA was isolated using the RNeasy Plus Kit (Qiagen). Agilent $4 \times 44$ Mouse Arrays were used to measure the expression of individual transcripts. Statistical analyses were performed using $\mathrm{R}$ and Bioconductor software. Background correction of raw Agilent data was performed using the normexp function in the limma package using an offset of 50 . Within-array normalization was performed using the normalizeWithinArrays function with the loess method. Last, arrays were normalized with the normalizeBetweenArrays function using the Aquantile method. Control probes were removed from the analysis. Data for duplicate probes on the Agilent array were averaged using the avereps function. Before comparison between groups, probes were filtered to ensure that only a single probe was represented for each gene using the featureFilter function with default parameters. Due to the small sample size in this analysis, variance filtering was not performed as this would likely have had an impact on the group comparisons performed using the limma package (Bourgon et al., 2010). For gene ontology analysis, additional parameters were added during filtering to ensure that the universe of genes was limited to include only those genes with a particular gene ontology definition. Linear regression was performed using limma, and $p$ values reported in the text as adjusted were corrected for multiple testing using the method of Benjamini and Hochberg (Benjamini and Hochberg, 1995). Gene sets for genes altered after application of antagonists were specified using cutoffs of log fold-change of $>0.5$ and an adjusted $p$ value of $<0.05$.

Gene set enrichment analysis was performed using the mRoast function in the limma package to test for enrichment of the AP5 gene sets in 
A

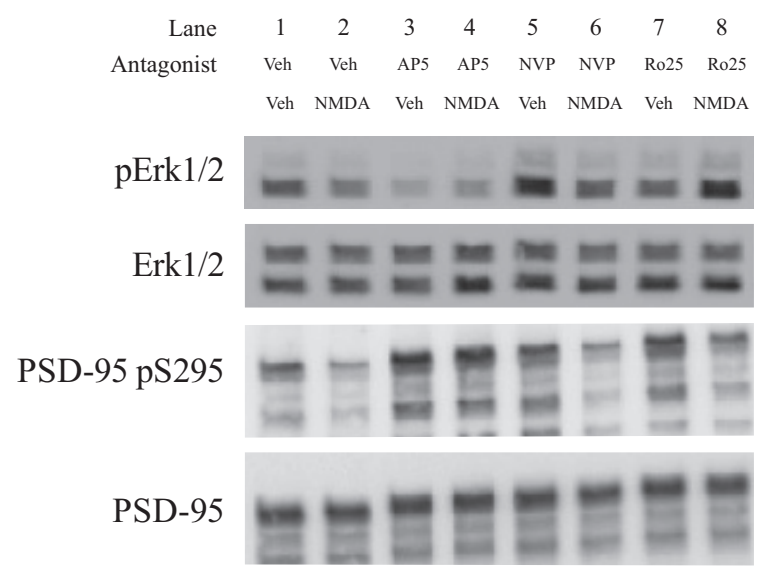

B $\begin{array}{lllllllll}\text { Antagonist } & \text { Veh } & \text { Veh } & \text { AP5 } & \text { AP5 } & \text { NVP } & \text { NVP } & \text { Ro25 } & \text { Ro25 }\end{array}$
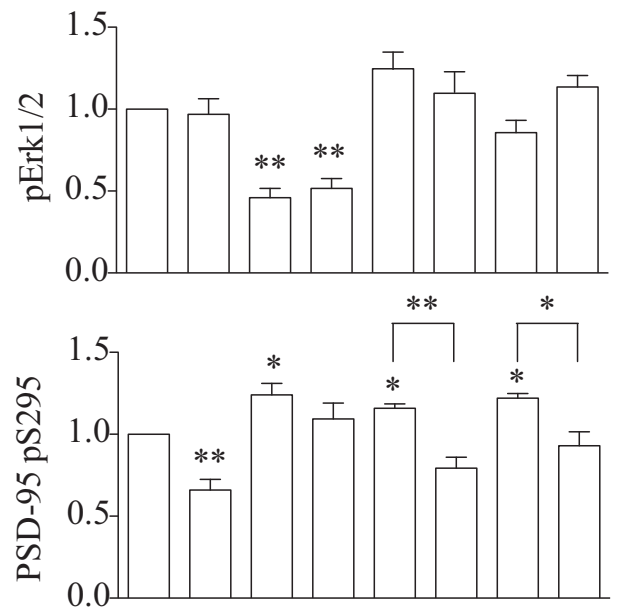

Figure 1. NMDARs are active in dissociated mouse hippocampal neuronal culture under basal conditions. $A$, Representative Western blots showing pErk1/2, total Erk1/2, PSD-95 pS295, and total PSD-95 levels in DIV 21 dissociated hippocampal neuronal cultures, treated with the indicated agents. $\boldsymbol{B}$, Quantitation of changes in pErk or PSD-95 pS295 levels after treatment with the indicated agents. Phosphorylated signals were normalized to total Erk1/2 or PSD-95 and then to vehicle control (Veh). ${ }^{*} p<0.05$, ${ }^{* *} p<0.01$. Student's $t$ test, $n=5$ independent experiments. Error bars indicate the SEM.

the NVP and Ro25 data. Gene ontology analysis was performed using the GOstats package with the gene universe defined as described above. Pathway analysis was performed using the Metacore package with default parameters (www.genego.com).

\section{Results}

\section{Basal NMDAR activity maintains Erk1/2 and PSD-95} S295 phosphorylation

NMDAR signaling was characterized in neuronal cultures under basal or stimulated conditions. Neuronal cultures were first treated with an NMDAR antagonist, AP5, followed by either vehicle or bath application of NMDA, to study NMDAR activity under basal or stimulated conditions, respectively. Bath application of NMDA activates both synaptic and extrasynaptic NMDARs (Hardingham and Bading, 2010).

Under basal conditions, treatment of DIV 21 hippocampal neuronal cultures for 15 min with AP5, the broad NMDAR antagonist, resulted in a decrease in Erk1/2 phosphorylation (pErk1/2) and an increase in the phosphorylation of Ser-295 on PSD-95 (PSD-95 pS295; Fig. 1A, lanes 1 and 3, B, quantitation). Total protein levels of Erk1/2 and PSD-95 were not altered (Fig. 1). These data confirm that NMDARs are active under basal conditions in our neuronal cultures, and suggest that basal NMDAR activity maintains Erk phosphorylation and suppresses PSD-95 S295 phosphorylation.

Consistent with previous reports (Kim et al., 2007; Nelson et al., 2013), treatment of DIV 21 hippocampal neuronal cultures for $15 \mathrm{~min}$ with vehicle followed by bath application of NMDA $(70 \mu \mathrm{M}$, for $10 \mathrm{~min}$ ) resulted in a decrease in PSD-95 S295 phosphorylation (Fig. 1A, lanes 1 and 2, B). The dephosphorylation of PSD-95 S295 was blocked by AP5 (Fig. 1A, lane 4). The above data could reflect either that both synaptic and extrasynaptic NMDARs inhibit PSD-95 S295 phosphorylation, or that synaptic, but not extrasynaptic, NMDARs inhibit PSD-95 S295 phosphorylation.

Additionally, bath application of NMDA did not alter pErk1/2 (Fig. 1, lane 2) or affect the decrease in pErk1/2 induced by AP5
(Fig. 1, lanes 3 and 4). This is consistent with previous data (Ivanov et al., 2006) and could be explained by the observation that bath application of NMDA activates both synaptic and extrasynaptic NMDARs (Hardingham and Bading, 2010). As extrasynaptic and synaptic NMDARs have opposite effects on Erk1/2 phosphorylation, it would be reasonable that bath application of NMDA resulted in no significant change in Erk1/2 phosphorylation (Ivanov et al., 2006). Together, these data indicate that there are differences between the downstream effects of basal and NMDA-induced NMDAR signaling.

Neuronal cultures were also treated with the GluN2A-preferring NMDAR antagonist, NVP (Auberson et al., 2002; Neyton and Paoletti, 2006) or the GluN2B-selective antagonist Ro25 (Fischer et al., 1997). Under basal conditions, as seen with AP5, both of these subtype-selective antagonists increased PSD-95 S295 phosphorylation (Fig. 1A, lanes 5 and 7, B, quantification). However, unlike AP5, neither subtype-selective antagonist reduced the phosphorylation of Erk1/2 (Fig. 1). Also, unlike AP5, neither NVP $(0.1 \mu \mathrm{M})$ nor Ro25 (1 $\mu \mathrm{M})$ blocked NMDA-induced dephosphorylation of PSD-95 S295 (Fig. 1A, lanes 5-8). The different effects of NVP and Ro25 versus AP5 could most simply be explained by the partial block of NMDARs by NVP and Ro25 versus the complete blockade by AP5.

\section{Basal NMDAR activity regulates the expression of a set of genes that is overlapping but distinct from those regulated by stimulated NMDARs \\ To characterize the downstream transcriptional targets of basal} NMDAR activity, microarray analysis was performed on RNA isolated from DIV 21 cultured hippocampal neurons treated for $6 \mathrm{~h}$ with vehicle, AP5 (100 $\mu \mathrm{M})$, Ro25 (1 $\mu \mathrm{M})$, or NVP $(0.1 \mu \mathrm{M}$; Fig. 2). After treatment with AP5, 467 genes were significantly downregulated (Fig. 2A, green dots) or upregulated (Fig. 2A, red dots) when compared with vehicle treatment [cutoff: adjusted $p$ value $<0.05$; absolute $\log _{2} \mathrm{FC}>0.5$; top 100 differentially expressed genes are shown in Table 1 (the entire microarray dataset 
A

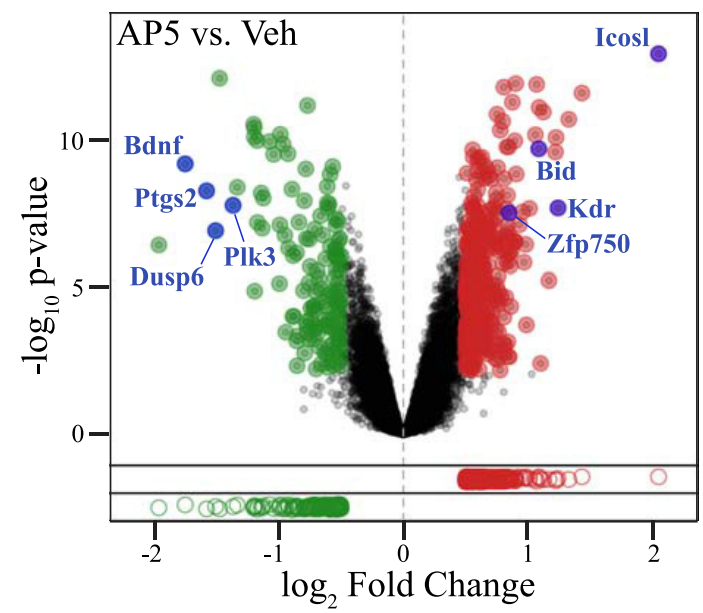

D

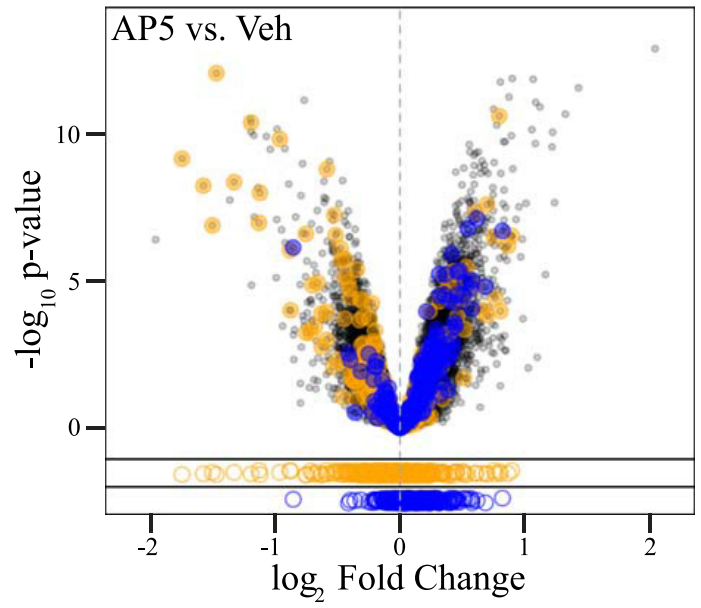

B

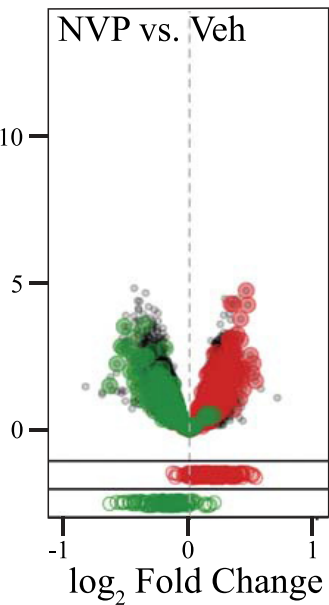

C

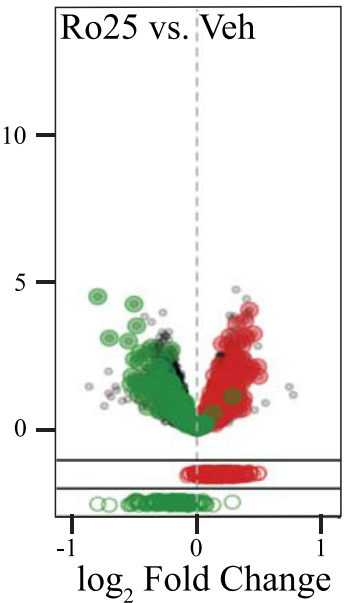

E

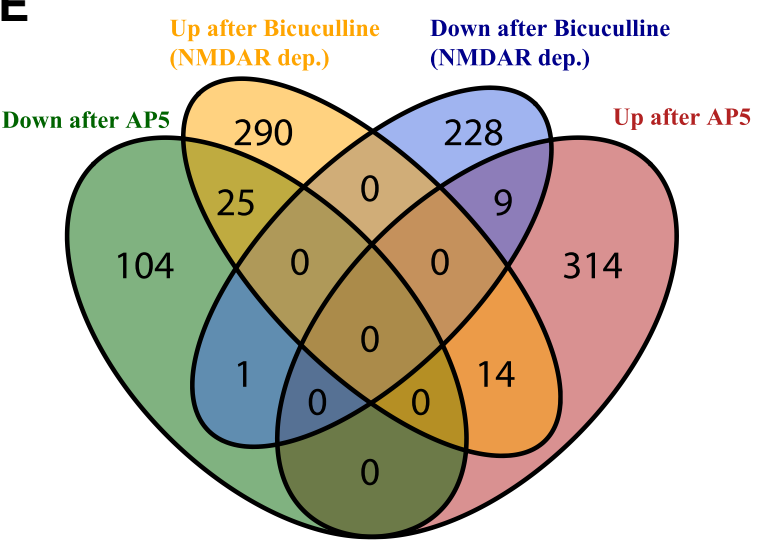

Down after Bicuculline

228 Up after AP5

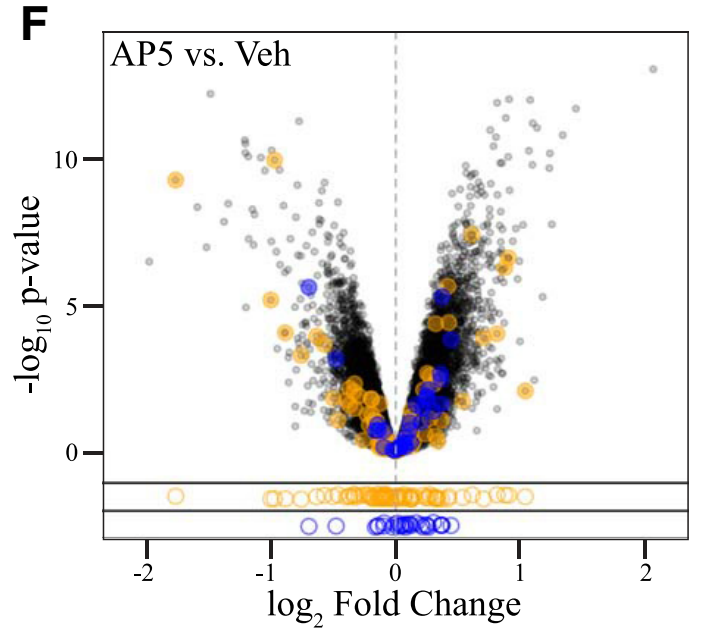

Figure 2. Inhibition of basal NMDAR activity induces robust gene expression changes. $\boldsymbol{A}-\boldsymbol{E}$, Volcano plots showing gene expression differences identified from comparison of AP5- (100 $\boldsymbol{\mu}$ M) versus vehicle (Veh)-treated neurons $(\boldsymbol{A}, \boldsymbol{D}, \boldsymbol{E})$, NVP- $(0.1 \mu \mathrm{m})$ versus vehicle-treated neurons $(\boldsymbol{B})$, or Ro25- $(1 \mu \mathrm{m})$ versus vehicle-treated neurons $(\boldsymbol{C})$. Each circle represents an individual gene. The $x$-axis indicates $\log _{2}$ Fold Change (FC) of the mRNA of that gene versus vehicle, and the $y$-axis indicates the $-\log _{10}$ unadjusted $p$ value of that change. Beneath each volcano plot is a strip chart showing the location in the fold-change axis of each gene colored in the volcano plot. The red-and green-colored circles are the same set of genes across $A-C$, and represent those genes significantly upregulated (red) and downregulated (green) from comparison of AP5 versus vehicle-treated neurons (absolute $\log _{2} \mathrm{FC}>0.5 ; p<0.05$ ). The genes colored in $\boldsymbol{D}$ are those genes that were significantly upregulated (orange) or downregulated (blue) by bicuculline-activated NMDAR signaling [bicuculline (NMDAR dep.); Zhang et al., 2007]. The genes colored in $\boldsymbol{F}$ represent those genes significantly upregulated (orange) or downregulated (blue) by glutamate bath application-induced extrasynaptic NMDAR signaling (NMDAR dep.; Zhang et al., 2007). $\boldsymbol{E}$, $\boldsymbol{F}$, Venn diagram showing the overlaps of the significantly altered genes from this study with the significantly altered genes from the study of Zhang et al., 2007 (colored circles in $\boldsymbol{D}$ are represented in $\boldsymbol{E}$; and colored circles in $\boldsymbol{F}$ are represented in $\mathbf{G}$ ). The numbers shown in each sector of the Venn diagram are the number of genes in each category. 
Table 1. Top 100 genes ranked by $p$ value that were significantly altered after $6 \mathrm{~h}$ of $100 \mu \mathrm{m}$ AP5 treatment versus vehicle treatment of DIV 21 dissociated hippocampal neuronal cultures

\begin{tabular}{|c|c|c|c|c|c|c|c|c|c|}
\hline Rank & Gene ID & Gene symbol & $\log _{2} F C$ & $p$ value & Rank & Gene ID & Gene symbol & $\log _{2} F C$ & $p$ value \\
\hline 1 & A_51_P311694 & Ypel5 & 0.96 & $8.52 \mathrm{E}-08$ & 51 & A_52_P318438 & Nab1 & -0.78 & $1.06 \mathrm{E}-05$ \\
\hline 2 & A_51_P282673 & Ccdc126 & 0.93 & 8.63E-08 & 52 & A_51_P223058 & Cgn & 1.49 & 1.07E-05 \\
\hline 3 & A_51_P239654 & Nr4a1 & -1.51 & $8.63 \mathrm{E}-08$ & 53 & A_52_P407007 & 4632415L05Rik & 0.55 & $1.08 \mathrm{E}-05$ \\
\hline 4 & A_51_P520966 & $|\cos |$ & 2.44 & $8.63 \mathrm{E}-08$ & 54 & A_51_P375201 & Plk3 & -1.63 & $1.13 \mathrm{E}-05$ \\
\hline 5 & A_52_P402319 & $\operatorname{Med} 20$ & 1.14 & $1.09 \mathrm{E}-07$ & 55 & A_52_P598309 & 1500012F01Rik & 0.64 & $1.23 \mathrm{E}-05$ \\
\hline 6 & A_51_P311905 & 2610002l17Rik & 0.80 & $1.09 \mathrm{E}-07$ & 56 & A_51_P171200 & Golm1 & 0.68 & $1.39 \mathrm{E}-05$ \\
\hline 7 & A_51_P347634 & Fam105a & 1.44 & $1.15 \mathrm{E}-07$ & 57 & A_51_P433026 & Ppapdc2 & -0.91 & $1.39 \mathrm{E}-05$ \\
\hline 8 & A_52_P412417 & Tnfaip3 & -0.88 & $1.15 \mathrm{E}-07$ & 58 & A_52_P213932 & Adamts1 & -0.99 & $1.43 \mathrm{E}-05$ \\
\hline 9 & A_51_P340699 & Rasl11a & -1.36 & $1.15 \mathrm{E}-07$ & 59 & A_51_P450226 & Kpna4 & 0.98 & $1.48 \mathrm{E}-05$ \\
\hline 10 & A_51_P301435 & B3galt5 & 1.30 & $1.15 \mathrm{E}-07$ & 60 & A_51_P203710 & Taf8 & 0.78 & $1.48 \mathrm{E}-05$ \\
\hline 11 & A_51_P515532 & Tmem200a & -1.13 & $1.61 \mathrm{E}-07$ & 61 & A_52_P515370 & Rit1 & 0.58 & $1.90 \mathrm{E}-05$ \\
\hline 12 & A_51_P282760 & Per2 & -1.27 & $1.93 \mathrm{E}-07$ & 62 & A_52_P47781 & Slitrk3 & 1.09 & $1.94 \mathrm{E}-05$ \\
\hline 13 & A_52_P510592 & Adamts2 & 1.87 & 2.85E-07 & 63 & A_51_P322941 & Dok7 & 1.10 & 1.94E-05 \\
\hline 14 & A_51_P195958 & Phlda1 & -1.23 & $2.85 \mathrm{E}-07$ & 64 & A_51_P148684 & Pou6f2 & 1.11 & $1.96 \mathrm{E}-05$ \\
\hline 15 & A_51_P277336 & Sdpr & 1.12 & $3.50 \mathrm{E}-07$ & 65 & A_51_P446558 & 1810026J23Rik & 0.60 & $2.25 \mathrm{E}-05$ \\
\hline 16 & A_51_P208330 & Camkk1 & 0.90 & $3.68 \mathrm{E}-07$ & 66 & A_51_P278893 & $\mathrm{Hdac5}$ & -0.47 & $2.26 \mathrm{E}-05$ \\
\hline 17 & A_51_P295420 & Zc3h7a & 0.80 & $3.68 \mathrm{E}-07$ & 67 & A_51_P174264 & $\mathrm{C} 2 \mathrm{~cd} 4 \mathrm{c}$ & 1.08 & $2.27 \mathrm{E}-05$ \\
\hline 18 & A_51_P288479 & Slc25a29 & 0.54 & $4.96 \mathrm{E}-07$ & 68 & A_51_P255805 & Fhdc1 & -0.54 & $2.40 \mathrm{E}-05$ \\
\hline 19 & A_52_P406141 & Wwox & 1.31 & $6.02 \mathrm{E}-07$ & 69 & A_51_P421559 & Bspry & 0.91 & $2.88 \mathrm{E}-05$ \\
\hline 20 & A_51_P433338 & Cdk20 & 0.81 & $6.02 \mathrm{E}-07$ & 70 & A_52_P305279 & Spata13 & 0.87 & $2.88 \mathrm{E}-05$ \\
\hline 21 & A_51_P433810 & Npas4 & -3.45 & $6.73 \mathrm{E}-07$ & 71 & A_51_P406008 & Fam203a & 0.49 & $3.05 \mathrm{E}-05$ \\
\hline 22 & A_52_P237652 & 2610035D17Rik & 1.33 & $6.73 \mathrm{E}-07$ & 72 & A_51_P389751 & Relb & -0.73 & $3.05 \mathrm{E}-05$ \\
\hline 23 & A_51_P315904 & Gadd45g & 0.82 & 7.05E-07 & 73 & A_51_P437289 & $\mathrm{BC} 017612$ & -1.00 & $3.05 E-05$ \\
\hline 24 & A_52_P319438 & Ankrd37 & -1.23 & $7.08 \mathrm{E}-07$ & 74 & A_51_P261999 & 2410075B13Rik & 0.71 & $3.44 \mathrm{E}-05$ \\
\hline 25 & A_52_P357402 & Mlst8 & 0.68 & $9.22 \mathrm{E}-07$ & 75 & A_51_P228974 & $0 \mathrm{gfod} 2$ & 0.50 & $3.94 \mathrm{E}-05$ \\
\hline 26 & A_52_P574653 & Bid & 1.16 & $9.68 \mathrm{E}-07$ & 76 & A_51_P465582 & Hdhd3 & 0.53 & $4.20 \mathrm{E}-05$ \\
\hline 27 & A_51_P241068 & Dkk2 & -2.10 & $1.30 \mathrm{E}-06$ & 77 & A_52_P521382 & Cox16 & -1.83 & 4.39E-05 \\
\hline 28 & A_51_P333831 & 2010004M13Rik & 0.71 & $1.64 \mathrm{E}-06$ & 78 & A_51_P324871 & Cybasc3 & -0.46 & 4.40E-05 \\
\hline 29 & A_51_P513941 & Lrpap1 & 0.58 & $2.36 \mathrm{E}-06$ & 79 & A_51_P342622 & $\operatorname{Ccdc} 28 \mathrm{a}$ & 1.50 & 4.46E-05 \\
\hline 30 & A_51_P254855 & Ptgs2 & -2.30 & $2.71 \mathrm{E}-06$ & 80 & A_52_P149364 & Armcx6 & 0.51 & 4.46E-05 \\
\hline 31 & A_51_P477121 & Pmaip1 & 1.09 & $2.99 \mathrm{E}-06$ & 81 & A_51_P139651 & Nos3 & 0.58 & $4.46 \mathrm{E}-05$ \\
\hline 32 & A_52_P547491 & 1520402A15Rik & -1.07 & $2.99 \mathrm{E}-06$ & 82 & A_51_P315890 & Kenk6 & -1.70 & 4.46E-05 \\
\hline 33 & A_52_P384100 & Bdnf & -1.90 & $3.24 \mathrm{E}-06$ & 83 & A_51_P138044 & Foxo1 & -1.03 & 4.71E-05 \\
\hline 34 & A_51_P416689 & Ext1 & -0.68 & $3.42 \mathrm{E}-06$ & 84 & A_51_P273130 & Mrpl9 & 0.45 & 4.71E-05 \\
\hline 35 & A_52_P126266 & Prkab2 & 1.28 & $3.45 \mathrm{E}-06$ & 85 & A_51_P416397 & Tbc1d22a & 0.47 & 4.79E-05 \\
\hline 36 & A_51_P272448 & Kctd2 & 0.58 & $3.76 \mathrm{E}-06$ & 86 & A_51_P137236 & Olfm1 & 0.63 & $4.98 \mathrm{E}-05$ \\
\hline 37 & A_52_P92398 & Bbs12 & -0.63 & 4.07E-06 & 87 & A_51_P302453 & Lhfpl2 & 0.86 & 4.99E-05 \\
\hline 38 & A_52_P230178 & Zfp605 & 0.85 & 4.07E-06 & 88 & A_52_P134228 & Lsm11 & -0.69 & 4.99E-05 \\
\hline 39 & A_51_P261324 & Fbx033 & -0.57 & 4.61E-06 & 89 & A_52_P274496 & Tspan18 & 0.60 & 5.17E-05 \\
\hline 40 & A_51_P110814 & Nudt9 & -0.66 & $4.68 \mathrm{E}-06$ & 90 & A_51_P115715 & Asb2 & 0.84 & $5.42 \mathrm{E}-05$ \\
\hline 41 & A_52_P305246 & Nudt4 & -0.64 & $4.68 \mathrm{E}-06$ & 91 & A_51_P296608 & Gadd45a & 0.68 & $5.52 \mathrm{E}-05$ \\
\hline 42 & A_51_P267447 & Adam19 & -0.80 & $6.39 \mathrm{E}-06$ & 92 & A_51_P105810 & $\mathrm{Gtf} 3 \mathrm{C} 5$ & 0.48 & $5.89 \mathrm{E}-05$ \\
\hline 43 & A_51_P509971 & Plekho1 & -0.79 & $7.05 \mathrm{E}-06$ & 93 & A_52_P38659 & Tchp & 0.55 & 5.90E-05 \\
\hline 44 & A_51_P165834 & Dclk2 & 0.50 & 7.41E-06 & 94 & A_52_P287927 & Lrrfip2 & -0.48 & $5.90 \mathrm{E}-05$ \\
\hline 45 & A_51_P274039 & Crcp & 0.82 & 7.41E-06 & 95 & A_52_P184052 & Smg7 & 0.76 & $6.00 \mathrm{E}-05$ \\
\hline 46 & A_51_P402160 & Zfp750 & 2.89 & $9.44 \mathrm{E}-06$ & 96 & A_52_P112931 & 3110002H16Rik & 0.43 & $6.22 \mathrm{E}-05$ \\
\hline 47 & A_51_P336282 & Npy1r & -0.89 & $9.69 \mathrm{E}-06$ & 97 & A_51_P348227 & Stoml1 & 0.45 & $6.25 \mathrm{E}-05$ \\
\hline 48 & A_51_P268343 & Aagab & 0.71 & $9.69 \mathrm{E}-06$ & 98 & A_52_P512955 & Anln & 0.53 & $6.25 \mathrm{E}-05$ \\
\hline 49 & A_51_P308347 & Dact2 & 0.74 & $9.69 \mathrm{E}-06$ & 99 & A_51_P427425 & Slc25a38 & 0.59 & $6.64 \mathrm{E}-05$ \\
\hline 50 & A_51_P316553 & $\mathrm{Kdr}$ & 1.81 & $1.06 \mathrm{E}-05$ & 100 & A_51_P400107 & Furin & -0.52 & $7.64 \mathrm{E}-05$ \\
\hline
\end{tabular}

is available from the National Center for Biotechnology Information with GEO ID GSE54708)]. Validation by quantitative RT-PCR (qRT-PCR) of a subset of gene expression changes identified from the microarray is shown in Figure 3A.

In contrast to AP5, no significant gene expression changes were observed by microarray after the treatment of neurons with either NVP or Ro25 (as with AP5, significant gene expression changes were defined using an adjusted $p$ value of $<0.05$ and an absolute $\log _{2} \mathrm{FC}$ of $>0.5$ ). However, other data presented here indicated that both NVP $(0.1 \mu \mathrm{M})$ and Ro25 $(1 \mu \mathrm{M})$ significantly impacted phosphorylation of PSD-95 S295, and altered the mRNA expression level of some target genes (Figs. 1, 3A). Therefore, we took a more sensitive approach by examining the overall effect of NVP and Ro25 on two sets of genes: all of the genes significantly upregulated by AP5, and all of those downregulated by AP5 (Fig. 2A, red and green circles, respectively). Notably, these aggregated gene sets were significantly altered after NVP or Ro25 treatment (Fig. 2B, C; NVP: up $p=0.014$, down $p=$ 0.008 ; Ro25: up $p=0.008$, down $p=0.004$ ). While the gene expression changes were generally smaller in magnitude after NVP or Ro25 treatment than after AP5 treatment, the direction of change observed with the aggregated gene sets was broadly consistent across all three treatments. These results suggest that the two subtype-selective NMDAR antagonists induce a 
A

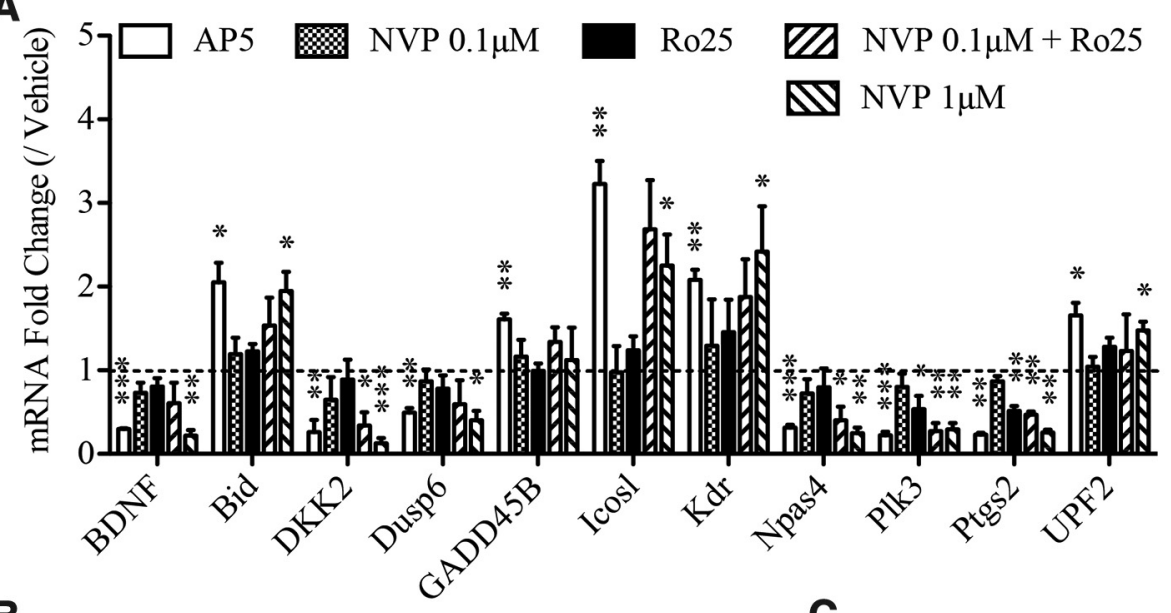

B
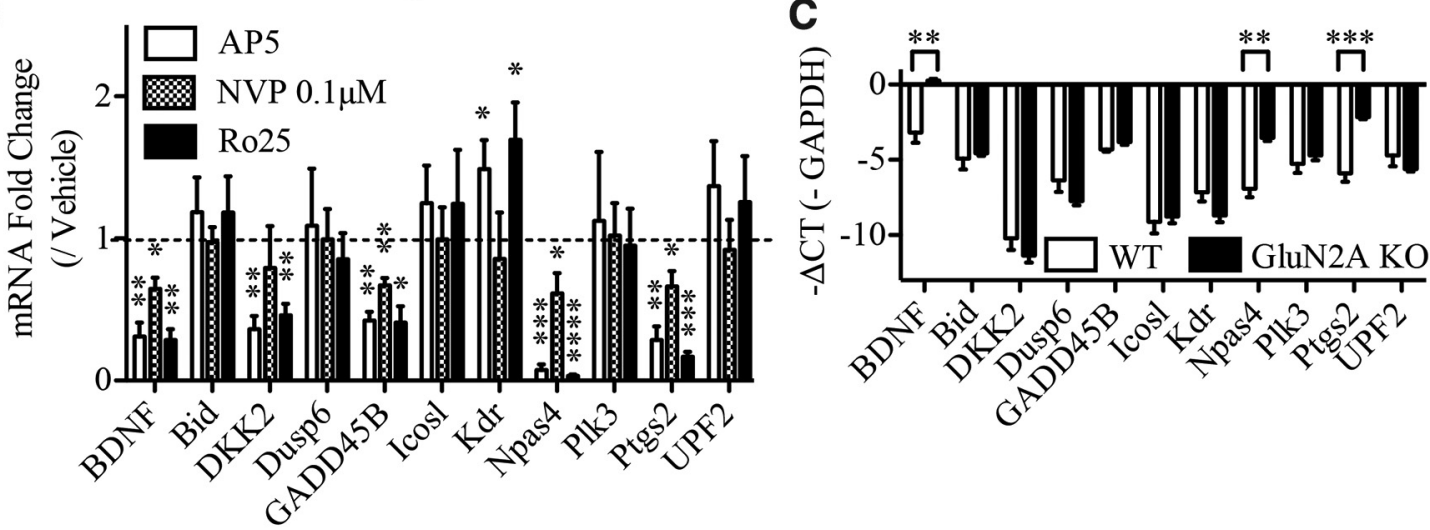

D

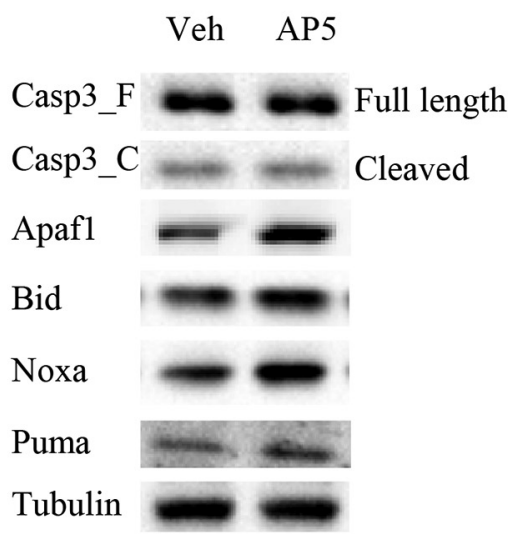

E

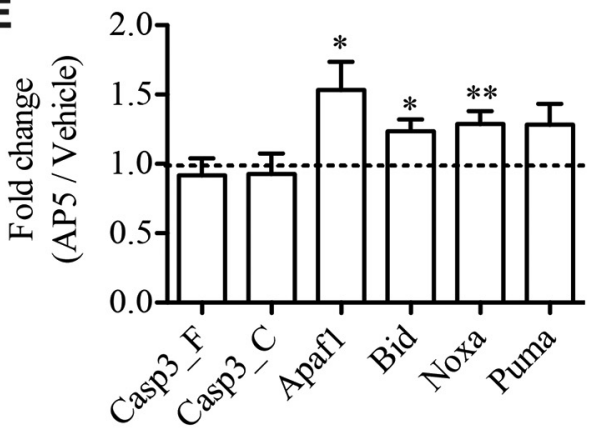

Figure 3. qRT-PCR and Western blot measurement of gene expression changes induced by treatment with NMDAR antagonists in WT and GluN2A KO neurons. $A$, $B$, Changes in mRNA levels in dissociated hippocampal neurons from WT $(\boldsymbol{A})$ or GluN2A KO (B) mice of a panel of genes were measured after selected treatment with AP5 (100 $\mu \mathrm{M}), \operatorname{NVP}(0.1$ and $1 \mu \mathrm{M}), \operatorname{Ro} 25(1 \mu \mathrm{M})$, or NVP $(0.1$ $\mu \mathrm{m})$ plus Ro25 $(1 \mu \mathrm{m})$ for $6 \mathrm{~h}$. Fold change is normalized to vehicle. GAPDH was used as an internal control to normalize total mRNA level of each sample. C, Expression level of the selected mRNAs was measured by comparing their qRT-PCR circle times (CT) with GAPDH CT ( $-\Delta \mathrm{CT}$ is defined by the circle time of GAPDH minus the circle time of the gene of measurement). $n=3-4$ independent experiments. D, E, Western blot of apoptosis-related proteins from WT neurons treated with vehicle or AP5 for $6 \mathrm{~h}(\boldsymbol{D})$. Quantified in $\boldsymbol{E}$. Error bars show SEM. ${ }^{*} p<0.05,{ }^{* *} p<0.01$, ${ }^{* * *} p<0.001$, ${ }^{* * * *} p<0.0001$, Student's $t$ test. $n=12$ independent experiments.

similar but weaker transcriptional response compared with the broad antagonist AP5.

As GluN2A-containing NMDARs are the predominant synaptic NMDARs in mature neurons, it is surprising the GluN2A-preferring antagonist NVP (at $0.1 \mu \mathrm{M})$ did not induce robust gene expression changes similar to the broad antagonist AP5 $(100 \mu \mathrm{M})$. To test the hypothesis that the weak gene expression effect is due to insufficient blockade of GluN2A-NMDARs by $0.1 \mu \mathrm{M}$ NVP, we performed three different experiments.
First, we coapplied both Ro25 $(1 \mu \mathrm{M})$ and NVP $(0.1 \mu \mathrm{M})$ to neuronal cultures and measured the impact of this cotreatment on the expression of genes that were significantly altered by AP5 (Fig. 3A). Interestingly, coapplication of NVP and Ro25 caused larger gene expression changes than those seen with either antagonist on their own, and, these changes were similar in magnitude to those seen by treatment with AP5 (Fig. 3A). This is consistent with a model in which NVP $(0.1 \mu \mathrm{M})$ and Ro25 $(1 \mu \mathrm{M})$ have a weak effect on gene expression because individually they cause only partial, and largely nonoverlapping, inhibition of basal NMDAR signaling. 
Table 2. Genes downregulated by AP5 and also upregulated by bicuculline-induced NMDAR activity

\begin{tabular}{|c|c|c|c|c|}
\hline Entrez & Symbol & Name & $\log _{2} \mathrm{FC}$ & $p$ value \\
\hline 11838 & Arc & $\begin{array}{l}\text { Activity-regulated cytoskeletal-associated } \\
\text { protein }\end{array}$ & -2.75 & $5.0 \mathrm{E}-10$ \\
\hline 15370 & Nr4a1 & $\begin{array}{l}\text { Nuclear receptor subfamily 4, group A, } \\
\text { member } 1\end{array}$ & -2.33 & $4.8 \mathrm{E}-09$ \\
\hline 12064 & Bdnf & Brain-derived neurotrophic factor & -1.69 & $1.4 \mathrm{E}-08$ \\
\hline 19225 & Ptgs2 & Prostaglandin-endoperoxide synthase 2 & -2.03 & $3.9 \mathrm{E}-08$ \\
\hline 225872 & Npas4 & Neuronal PAS domain protein 4 & -3.38 & $1.3 \mathrm{E}-07$ \\
\hline 17873 & Gadd45b & $\begin{array}{l}\text { Growth arrest and DNA-damage-inducible } \\
\quad 45 \beta\end{array}$ & -1.13 & $6.4 \mathrm{E}-07$ \\
\hline 19735 & Rgs2 & Regulator of G-protein signaling 2 & -1.13 & $7.9 \mathrm{E}-07$ \\
\hline 67603 & Dusp6 & Dual-specificity phosphatas & -1.20 & $1.0 \mathrm{E}-06$ \\
\hline 68404 & Nrn1 & Neuritin 1 & -0.66 & $6.2 \mathrm{E}-06$ \\
\hline 23828 & Bves & Blood vessel epicardial substance & -0.80 & $1.7 \mathrm{E}-05$ \\
\hline 68895 & Rasl11a & RAS-like, family 11, member A & -1.18 & $1.9 \mathrm{E}-04$ \\
\hline 19252 & Dusp1 & Dual-specificity phosphatase 1 & -0.70 & $3.1 \mathrm{E}-04$ \\
\hline 15982 & Ifrd1 & $\begin{array}{l}\text { Interferon-related developmental } \\
\quad \text { regulator } 1\end{array}$ & -0.90 & $3.6 \mathrm{E}-04$ \\
\hline 12228 & Btg3 & B-cell translocation gene 3 & -0.79 & $3.7 \mathrm{E}-04$ \\
\hline 320292 & Rasgef1b & RasGEF domain family, member $1 \mathrm{~B}$ & -0.72 & $3.9 \mathrm{E}-04$ \\
\hline 24066 & Spry4 & Sprouty homolog 4 (Drosophila) & -1.07 & $7.4 \mathrm{E}-04$ \\
\hline 13654 & Egr2 & Early growth res & -0.90 & $8.6 \mathrm{E}-04$ \\
\hline 11911 & Atf4 & Activating transcription factor 4 & -0.58 & $4.9 \mathrm{E}-03$ \\
\hline 140743 & Rem2 & $\begin{array}{l}\text { Rad- and gem-related GTP binding } \\
\text { protein } 2\end{array}$ & -0.54 & $6.2 \mathrm{E}-03$ \\
\hline 11504 & Adamts1 & $\begin{array}{l}\text { A disintegrin-like and metallopeptidase } \\
\text { (reprolysin type) with thrombospondin } \\
\text { type } 1 \text { motif, } 1\end{array}$ & -0.67 & 7.1E-03 \\
\hline 16477 & Junb & Jun-B oncogene & -0.71 & $9.8 \mathrm{E}-03$ \\
\hline 13655 & Egr3 & Early growth response 3 & -0.92 & $9.8 \mathrm{E}-03$ \\
\hline 77889 & Lbh & Limb-bud and heart & -0.59 & $1.1 \mathrm{E}-02$ \\
\hline 18227 & $\mathrm{Nr} 4 \mathrm{a} 2$ & $\begin{array}{l}\text { Nuclear receptor subfamily 4, group A, } \\
\text { member } 2\end{array}$ & -0.92 & $3.0 \mathrm{E}-02$ \\
\hline 214855 & Arid5a & AT-rich interactive domain 5A (MRF1-like) & -0.58 & $3.5 \mathrm{E}-02$ \\
\hline 14282 & Fosb & FBJ osteosarcoma oncogene B & -1.01 & $4.2 \mathrm{E}-02$ \\
\hline
\end{tabular}

The 25 genes that were downregulated by AP5 (this study) and also upregulated by bicuculline-induced NMDAR activity (from Zhang et al., 2007) are shown. See also Figure 2E.

Second, we tested the effects of NVP at a higher concentration of $1 \mu \mathrm{M}$. At this concentration, NVP is not specific for GluN2A receptors, and can block both GluN2A- and GluN2B-containing NMDARs (Neyton and Paoletti, 2006). NVP at $1 \mu \mathrm{M}$ induced much larger gene expression changes than NVP at $0.1 \mu \mathrm{M}$, and, these changes were similar in magnitude to those seen after AP5 treatment (Fig. 3A). These data are also consistent with the idea that the weak effect of $0.1 \mu \mathrm{M}$ NVP is due to partial inhibition of NMDARs.

Third, we tested the NMDAR inhibitors on neurons from GluN2A KO mice (Kadotani et al., 1996). In such neurons, Ro25sensitive GluN2B containing diheteromeric NMDARs should be the predominant, if not the only, subtype of NMDAR present. Treatment of GluN2A KO cultures with Ro25 induced a similar pattern of gene expression changes as seen after treatment with the broad inhibitor AP5 (Fig. 3B). Therefore, the weaker impact of Ro25 on gene expression regulation in WT cultures is likely because the predominant synaptic NMDARs are not Ro25sensitive GluN2B-containing NMDARs in these cultures.

As NMDAR signaling is highly context dependent (Hardingham and Bading, 2010), we also compared the gene expression changes we observed after the inhibition of NMDARs in basal cultures with the changes in gene expression resulting from the activation of NMDARs by treatment of cultures of bicuculline. Similar to the methodology used above, two gene sets reflecting
Table 3. Genes upregulated by AP5 and also downregulated by bicuculline-induced NMDAR activity

\begin{tabular}{|c|c|c|c|c|}
\hline Entrez & Symbol & Name & $\log _{2} \mathrm{FC}$ & $\overline{p \text { value }}$ \\
\hline 16918 & Mycl1 & $\begin{array}{l}\text { v-Myc myelocytomatosis viral oncogene } \\
\text { homolog 1, lung carcinoma derived } \\
\text { (avian) }\end{array}$ & 0.99 & $1.7 \mathrm{E}-05$ \\
\hline 73086 & Rps6ka5 & $\begin{array}{l}\text { Ribosomal protein } \$ 6 \text { kinase, } \\
\text { polypeptide } 5\end{array}$ & 1.48 & $1.4 \mathrm{E}-04$ \\
\hline 22770 & Zhx1 & Zinc fingers and homeoboxes 1 & 0.63 & $4.2 \mathrm{E}-03$ \\
\hline 267019 & Rps15a & Ribosomal protein S15A & 0.79 & $5.0 \mathrm{E}-03$ \\
\hline 241556 & Tspan18 & Tetraspanin 18 & 0.54 & $1.0 \mathrm{E}-02$ \\
\hline 215819 & Nhsl1 & NHS-like 1 & 1.10 & $1.0 \mathrm{E}-02$ \\
\hline 66315 & Senp7 & SUM01/sentrin specific peptidase 7 & 0.55 & $1.5 \mathrm{E}-02$ \\
\hline 74018 & Als2 & $\begin{array}{l}\text { Amyotrophic lateral sclerosis } 2 \\
\text { (juvenile) homolog (human) }\end{array}$ & 0.59 & $1.6 \mathrm{E}-02$ \\
\hline 22718 & Zfp60 & Zinc finger protein 60 & 1.20 & $1.8 \mathrm{E}-02$ \\
\hline 106064 & AW549877 & Expressed sequence AW549877 & 0.99 & $2.3 \mathrm{E}-02$ \\
\hline 78255 & Ralgps2 & $\begin{array}{l}\text { Ral GEF with PH domain and SH3 } \\
\text { binding motif } 2\end{array}$ & 0.63 & $3.0 \mathrm{E}-02$ \\
\hline 12395 & Runx1t1 & $\begin{array}{l}\text { Runt-related transcription factor } 1 ; \\
\text { translocated to } 1 \text { (cyclin D-related) }\end{array}$ & 0.62 & $3.1 \mathrm{E}-02$ \\
\hline
\end{tabular}

The nine genes that were upregulated by AP5 (this study) and also downregulated by bicuculline-induced NMDAR activity (from Zhang et al., 2007). See also Figure $2 E$.

the genes upregulated or downregulated by activated NMDARs were generated by identifying bicuculline-induced gene expression changes that were blocked by AP5 (data from Zhang et al., 2007). The behavior of these gene sets was analyzed in our microarray data from unstimulated neurons treated with AP5 (Fig. 2D, orange and blue dots, respectively). Importantly, the bicuculline-activated NMDAR upregulated gene set was significantly downregulated after AP5 treatment of basal cultures (Fig. 2D, orange dots; $p=0.01$ ), and the bicuculline-activated NMDAR downregulated gene set was significantly upregulated in our data after AP5 treatment (Fig. $2 D$, blue dots; $p=0.002$ ). These results suggest that there are individual genes that can be bidirectionally regulated by the inhibition or activation of NMDAR signaling. The 34 genes most significantly altered by both treatments are shown in Tables 2 and 3. However, the majority of the genes significantly altered by AP5 were not significantly altered by bicuculline-induced activation of NMDARs (Fig. 2E; cutoff levels for significant changes are as defined above), suggesting that they are novel NMDAR-dependent genes that are specifically regulated by basal NMDAR activity. For instance, of 337 genes significantly upregulated by AP5 in basal conditions, only 9 were downregulated and 14 were upregulated by NMDAR activation in bicuculline conditions (Fig. 2E).

Previous studies suggested that activation of synaptic NMDARs results in distinct gene expression differences compared with those seen after activation of extrasynaptic NMDARs (Zhang et al., 2007). Therefore, the gene expression changes induced by AP5 in basal conditions were compared with those caused by activation of extrasynaptic NMDARs (defined by Zhang et al., 2007 as bath glutamate-induced gene expression changes that were blocked by AP5). While the extrasynaptic NMDAR downregulated gene set was modestly and significantly upregulated in our data after AP5 treatment $(p=0.05$; Fig. $2 F$, blue dots), the extrasynaptic NMDAR upregulated gene set was not significantly downregulated in our data after AP5 treatment of basal cultures (Fig. $2 F$, orange dots). Only seven genes were bidirectionally altered by both treatments with our cutoff thresholds (Fig. 2G). Since the extrasynaptic NMDARregulated genes reflect a distinct downstream signaling pro- 


\begin{tabular}{|c|c|c|c|c|c|c|}
\hline Rank & $p$ value & Ratio & Pathway & Synapse & Apoptosis & HDAC \\
\hline 1 & $2.44 \mathrm{E}-10$ & $27: 65$ & Cardiac hypertrophy-NF-AT signaling in cardiac hypertrophy & & & Y \\
\hline 2 & $7.08 \mathrm{E}-10$ & 28:72 & Reproduction-GnRH signaling & & & Y \\
\hline 3 & $1.75 \mathrm{E}-08$ & $22: 54$ & Development-role of HDAC and CaMK in control of skeletal myogenesis & & & Y \\
\hline 4 & $1.33 \mathrm{E}-07$ & $23: 64$ & Development-regulation of EMT & & & \\
\hline 5 & $2.10 \mathrm{E}-07$ & $26: 80$ & Neurophysiological process-NMDA-dependent postsynaptic LTP in CA1 hippocampal neurons & Y & & \\
\hline 6 & $2.16 \mathrm{E}-06$ & $30: 111$ & Cytoskeleton remodeling-TGF, WNT, and cytoskeletal remodeling & & & \\
\hline 7 & $2.61 \mathrm{E}-06$ & $17: 45$ & Neurophysiological process-glutamate regulation of dopamine D1A receptor signaling & Y & & \\
\hline 8 & $3.00 \mathrm{E}-06$ & 18:50 & Immune response-Function of MEF2 in T lymphocytes & & & Y \\
\hline 9 & $3.62 \mathrm{E}-06$ & $15: 37$ & Development-MAG-dependent inhibition of neurite outgrowth & & & \\
\hline 10 & $4.03 \mathrm{E}-06$ & $14: 33$ & Apoptosis and survival-caspase cascade & & Y & \\
\hline 11 & $4.16 \mathrm{E}-06$ & $18: 51$ & Signal transduction-PKA signaling & & & \\
\hline 12 & $6.16 \mathrm{E}-06$ & $14: 34$ & Development-role of CDK5 in neuronal development & & & \\
\hline 13 & $6.37 \mathrm{E}-06$ & $11: 22$ & Development-thrombopoetin signaling via JAK-STAT pathway & & & \\
\hline 14 & $6.48 \mathrm{E}-06$ & $16: 43$ & Apoptosis and survival-FAS signaling cascades & & Y & \\
\hline 15 & $6.90 \mathrm{E}-06$ & $11: 26$ & Immune response-IL-10 signaling pathway & & & \\
\hline 16 & $7.06 \mathrm{E}-06$ & $27: 100$ & Cell adhesion- chemokines and adhesion & & & \\
\hline 17 & $7.76 \mathrm{E}-06$ & $18: 53$ & Apoptosis and survival-endoplasmic reticulum stress response pathway & & Y & \\
\hline 18 & $1.00 \mathrm{E}-05$ & $17: 49$ & Development-PEDF signaling & & & \\
\hline 19 & $1.28 \mathrm{E}-05$ & $16: 45$ & Neurophysiological process-Receptor-mediated axon growth repulsion & & & \\
\hline 20 & $1.36 \mathrm{E}-05$ & $17: 50$ & Development-GM-CSF signaling & & & \\
\hline 21 & $2.28 \mathrm{E}-05$ & $12: 32$ & Apoptosis and survival-granzyme B signaling & & Y & \\
\hline
\end{tabular}

The top enriched pathways are shown, ranked by $p$ value (Fisher's exact test). The ratio shows the number of genes that were significantly altered by AP5 divided by the total number of genes in that specific pathway. EMT, Epithelial-to-mesenchymal transition; GnRH, gonadotropin-releasing hormone; PKA, protein kinase A; GM-CSF, granulocyte macrophage colony-stimulating factor; PEDF, pigment epithelium-derived factor; MAG, myelin-associated glycoprotein; MEF2, myocyte enhancer factor 2. Y indicates that the pathway is related to either Synpase, Apoptosis, or HDAC.

cess than that seen with synaptic NMDAR-regulated genes, these data could be explained by the lack of extrasynaptic NMDAR activity under basal conditions.

\section{Gene ontology and pathway analysis reveal enrichment of} novel pathways in genes regulated by basal NMDAR activity Gene ontology analysis was used to highlight potential biological processes regulated by NMDAR basal activity. Within the most significant AP5-dependent gene expression changes, there was a significant over-representation of genes involved in several functions, including apoptosis, synaptic function, and class IIa HDACrelated pathways (Table 4 ).

Four of the top 21 AP5-affected pathways involved apoptosis (Table 4), suggesting that basal NMDAR activity is linked to apoptotic pathways. In detail, components of intrinsic apoptotic pathways were enriched in the genes that were altered by AP5 ( $p=9.0 \mathrm{E}-3$, Fisher's exact test; Taylor et al., 2008). These include significant upregulation of seven proapoptotic genes (Apaf1: $\log _{2} \mathrm{FC}=0.523, p=1.01 \mathrm{E}-3$; Bid: $\log _{2} \mathrm{FC}=1.090, p=1.06 \mathrm{E}-7$; Bim: $\log _{2} \mathrm{FC}=0.289, p=3.88 \mathrm{E}-2$; Casp2: $\log _{2} \mathrm{FC}=0.434, p=$ 1.22E-3; Hrk: $\log _{2} \mathrm{FC}=0.361, p=2.45 \mathrm{E}-2$; Noxa: $\log _{2} \mathrm{FC}=$ 1.060, $p=5.22 \mathrm{E}-8$; Puma: $\left.\log _{2} \mathrm{FC}=0.574, p=3.40 \mathrm{E}-3\right)$ and downregulation of an anti-apoptotic gene $\left(\mathrm{Bcl} 2: \log _{2} \mathrm{FC}=\right.$ $-0.287, p=3.67 \mathrm{E}-2)$. The identification of apoptosis-related pathways is consistent with the known role of synaptic NMDA receptor signaling in CREB-mediated neuronal survival (Hardingham et al., 2002) and anti-apoptotic gene expression changes (Lau and Bading, 2009; Léveillé et al., 2010). We further tested whether these mRNA level changes correlated with protein level changes for four of these genes with $\log _{2} \mathrm{FC}>0.5$ (Apaf1, Bid, Noxa, and Puma). Western blot analysis showed that AP5 treatment for $6 \mathrm{~h}$ significantly increased the protein levels of Apaf1 $(\mathrm{FC}=1.53 \pm 0.20, p=0.045), \mathrm{Bid}(\mathrm{FC}=1.24 \pm 0.08, p=$ $0.017)$, and Noxa $(\mathrm{FC}=1.29 \pm 0.09, p=0.009$; Fig. $3 D, E)$. Puma expression increased following AP5 treatment, but this change did not reach statistical significance $(\mathrm{FC}=1.28 \pm 0.15, p=$ 0.118 ). The expression of either a full-length or cleaved form of
Casp3 was not changed by AP5 treatment (Casp3_F: FC $=0.92 \pm$ $0.12, p=0.531$; Casp3_C: $\mathrm{FC}=0.93 \pm 0.15, p=0.645)$, suggesting that NMDAR inhibition was not sufficient to trigger activation of apoptotic pathways in these neurons (Fig. 3D,E).

Four of the top 10 enriched gene ontology classes contain members of the class IIa HDAC family (Table 4). HDACs are a class of enzymes that catalyze epigenetic histone modifications. Class IIa consists of HDAC4, HDAC5, HDAC7, and HDAC9, of which HDAC4, HDAC5, and HDAC9 are highly expressed in the brain (Haberland et al., 2009; Darcy et al., 2010). Class IIa HDACs are known as transcriptional repressors associated with brain disorders, but their neuronal functions are unclear (Haberland et al., 2009; Williams et al., 2010; Li et al., 2012). In our microarray results, HDAC4 was upregulated after AP5 treatment of neuronal cultures $\left(\log _{2} \mathrm{FC}=0.48, p=1.4 \mathrm{E}-2\right)$, and HDAC5 and HDAC9 were both downregulated (HDAC5: $\log _{2} \mathrm{FC}=$ $-0.57, p=3.1 \mathrm{E}-7$; HDAC9: $\log _{2} \mathrm{FC}=-0.86, p=9.9 \mathrm{E}-3$; also see Table 1). qRT-PCR confirmed these changes showing that HDAC4 mRNA increased approximately twofold, while HDAC5 and HDAC9 fell by $\sim 30 \%$ and $\sim 50 \%$, respectively (Fig. $4 A$ ).

\section{Class IIa HDAC expression and subcellular localization are controlled by NMDAR activity}

Protein levels of HDAC4 and HDAC5 were measured by Western blotting. HDAC4 was significantly increased by $\sim 30 \%$ after AP5 treatment ( $p=0.007$; Fig. $4 B, D)$; HDAC5 protein levels fell with AP5, but the reduction did not reach significance $(p=0.12$; Fig. $4 C, D)$. The levels of HDAC4 and HDAC5 were also examined in the presence of TTX, which inhibits neuronal activity via blockade of action potentials. Treatment of neurons with TTX resulted in an $\sim 1.7$-fold increase in HDAC4 ( $p=0.043$ ), and an $\sim 0.6$-fold decrease in HDAC5 $(p=0.009)$. Lastly, levels of HDAC4 and HDAC5 were examined in neuronal cultures treated with PTX, a GABA $\mathrm{A}_{\mathrm{A}}$ antagonist that, like bicuculline, results in NMDAR activation (Hardingham et al., 2002). PTX had no significant effect on either HDAC4 or HDAC5 protein levels (Fig. 4B-D). This is consistent with previous reports in which stimulated NMDAR activity was not found to 
A

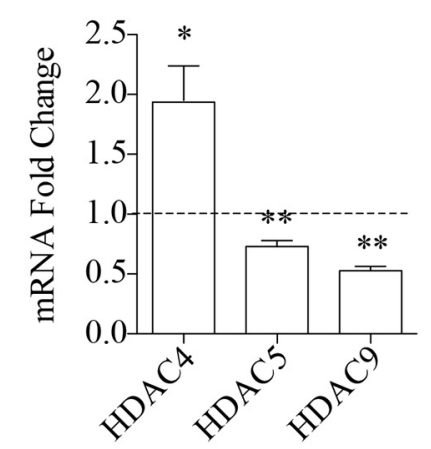

E

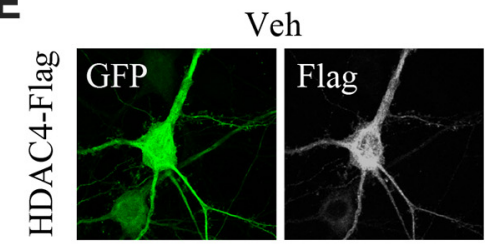

F

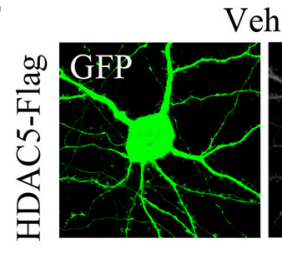

G
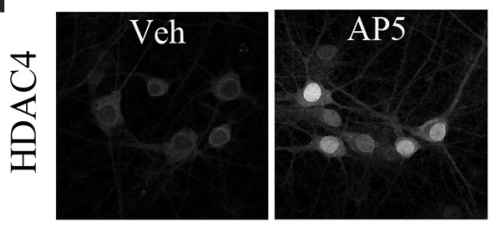

B

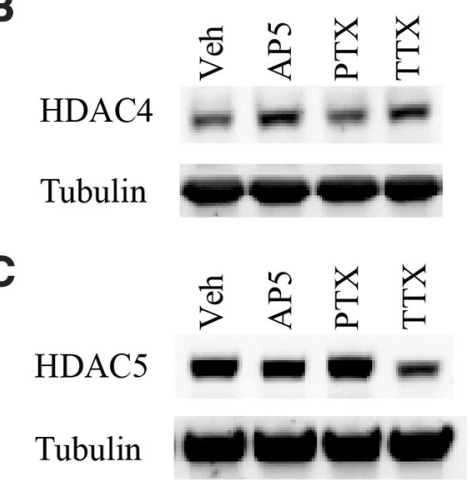

AP5

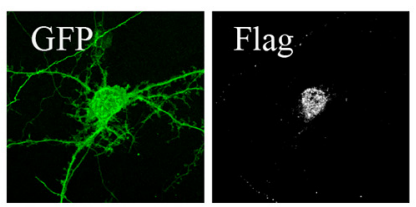

AP5
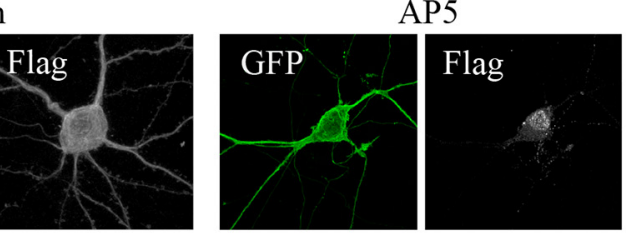

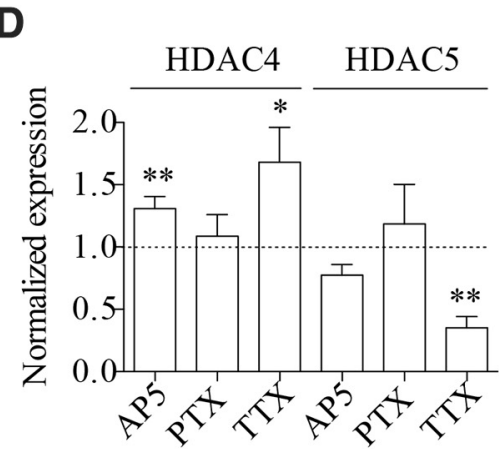

TTX

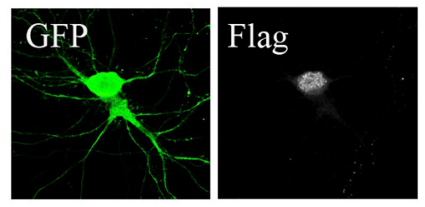

TTX
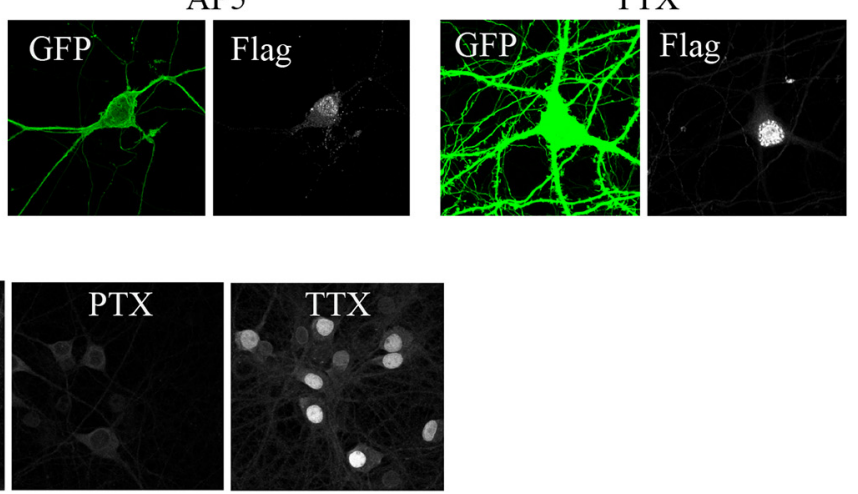

Figure 4. NMDAR and neuronal activity regulate expression and nuclear localization of class lla HDACs. $A, q R T-P C R$ results showing AP5-induced mRNA changes for HDAC4, HDAC5, and HDAC9 in dissociated hippocampal neuronal cultures (DIV 21), normalized to vehicle treatment. $\boldsymbol{B}-\boldsymbol{D}$, Representative Western blots showing the HDAC4 (B) and HDAC5 (C) protein level changes in DIV 21 dissociated hippocampal neuronal cultures treated with AP5, PTX, or TTX, as indicated; quantitation of Western blots from $\boldsymbol{B}$ and $\boldsymbol{C}$ is shown in $\boldsymbol{D}$. $\boldsymbol{E}, \boldsymbol{F}, \boldsymbol{C}$-terminally Flag-tagged HDAC4 (E) or HDAC5 (F) was cotransfected with GFP in neuronal cultures, and stained for GFP (left, green) and Flag (right) after $6 \mathrm{~h}$ of vehicle, AP5, or TTX treatment, as indicated. G, Endogenous HDAC4 immunostaining in dissociated cultures after $6 \mathrm{~h}$ of vehicle, AP5, PTX, or TTX treatment, as indicated. Error bars show SEM. ${ }^{*} p<0.05$, ${ }^{* *} p<0.01$, Student's $t$ test. $n=3-4$ independent experiments.

affect mRNA expression of HDAC4, HDAC5, or HDAC9 (Zhang et al,, 2007). These data highlight that, while activation of NMDARs does not alter levels of HDAC4 or HDAC5 protein, inhibition of basal NMDAR signaling significantly alters both HDAC4 and HDAC5 protein levels.

It has been reported that class IIa HDACs shuttle between the nucleus and cytoplasm in response to neuronal activity (Chawla et al., 2003; Bolger and Yao, 2005). After transient transfection, C-terminal Flag-tagged HDAC4 and HDAC5 were present diffusely in the cytoplasm in hippocampal pyramidal neurons under basal conditions (Fig. 4E,F). After $6 \mathrm{~h}$ of AP5 or TTX treatment, both HDAC4-Flag and HDAC5-Flag redistributed to the nucleus (Fig. $4 E, F$ ). Additionally, immunostaining of endogenous HDAC4 after vehicle, AP5, PTX, or TTX treatment showed that, whereas there was only diffuse cytoplasmic staining of HDAC4 after vehicle or PTX treatment, both TTX and AP5 induced strong nucleus-localized HDAC4 staining (Fig. 4G), which is consistent with previous data (Chawla et al., 2003; Sando et al., 2012).

The elevated expression of HDAC4 in response to AP5 treatment suggested that HDAC4 might be an important signaling component in low NMDAR activity conditions. Therefore, we generated two different shRNAs targeting HDAC4 (shH4_1 and shH4_2) to investigate its endogenous function. Both shRNAs were effective in knocking down protein levels of Flag-HDAC4 heterologously expressed in HEK293 cells (Fig. 5A). A lentiviral vector was used to express shH4_1 (shH4_1-lentivirus) or control shRNA (targeting firefly luciferase; shLuc-lentivrus) in dissociated hippocampal cultures. Additionally, Synapsin promoter-driven GFP was included in the lentiviral vectors to enable identification of infected neurons. One week after infection, a majority of neurons expressed GFP, indicating a high efficiency of infection (Fig. $5 B$ ). In control shLuc-lentivirus-infected cultures, faint cytoplasmic immunofluorescence marking endogenous HDAC4 was observed under basal conditions. After $6 \mathrm{~h}$ of AP5 or TTX treatment, anti-HDAC4 immunofluorescence revealed a strong nuclear signal in control shLuc-lentivirus-infected cultures (Fig. 5C,D). The AP5- or TTX-induced nuclear signal of HDAC4 was abolished by infection with the shH4_1-lentivirus (Fig. 5C,D), indicating that the signal represents endogenous HDAC4. Together, these experiments show that in conditions of neuronal hypoactivity and/or NMDAR blockade, HDAC4 is endogenously 
A

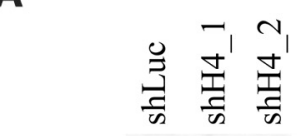

HDAC4

Tubulin
B

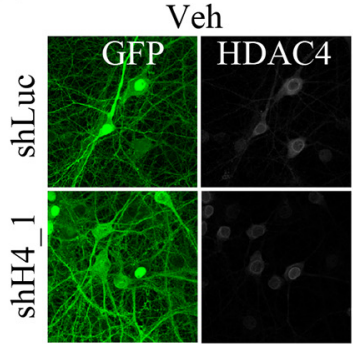

C

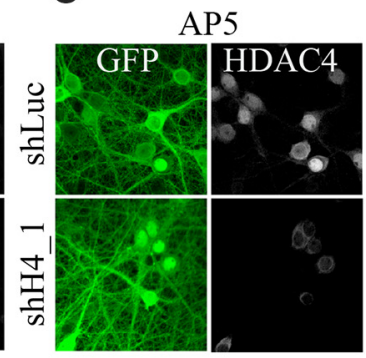

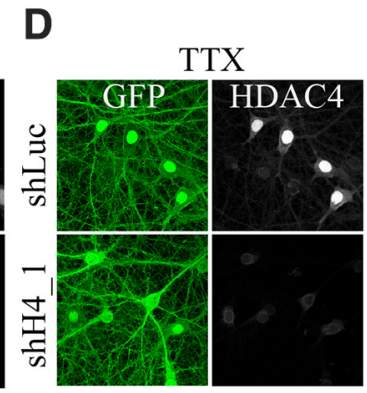

E $\square \operatorname{shLuc}$ AP5 $\otimes$ shH4_1 Veh $\square$ shH4_1 AP5 $\square$ shLuc PTX $\times$ shH4_1 Veh $\square$ shH4_1 PTX

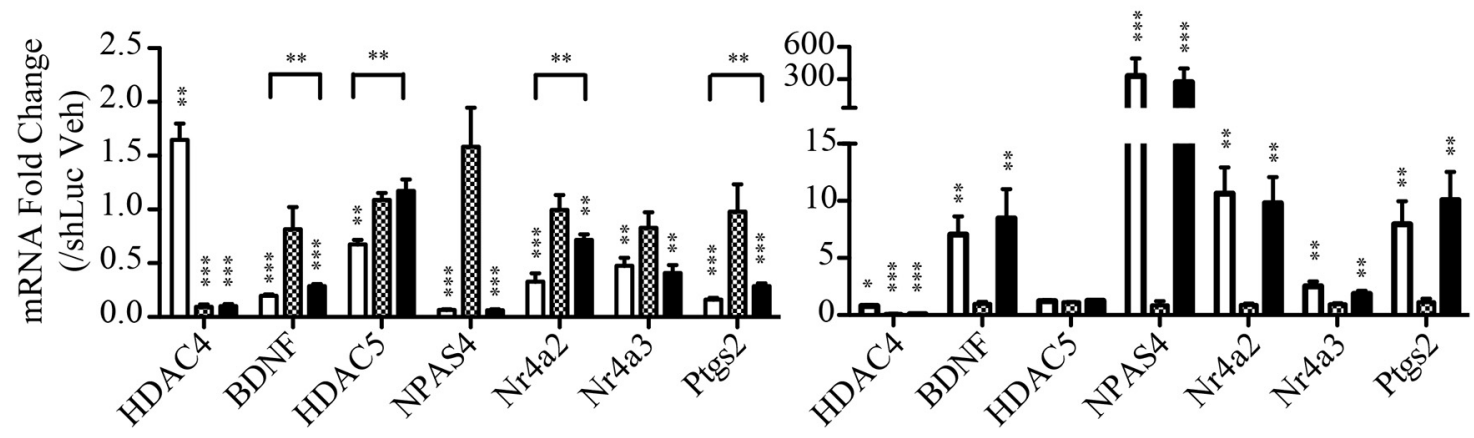

Figure 5. HDAC4 contributes to AP5-mediatedgenesuppression.A,Westemblotshowing HDAC4 expression in HEK293 cells aftercoexpressing HDAC4-Flag witheithershLuc, ShH4_1,orshH4_2.B-D,Immunostaining forGFPorendogenousHDAC4 indissociated neuronal culturesinfected with shLucorshH4_1 aftertreatmentwithvehicle (B),AP5(C), or TX (D) for6h.E, GRT-PCRmeasurements of mRNA expressioninneuronsinfected with shLucorshH4_1 after6h oftreatmentwithvehicleorAP5. ThefoldchangeofeachmRNA wasnormalized tovehicletreatmentinculturesinfected with shLuc.F, GRT-PCRmeasurements ofmRNAexpression inneurons infected with shLuc or shH4_1 after 6h of vehicle or PTX treatment. Error bars show SEM. ${ }^{*} p<0.05,{ }^{* *} p<0.01$, Student's $t$ test. $n=3-4$ independent experiments were performed.

induced at the mRNA and protein levels, and that the protein accumulates in the nucleus.

\section{HDAC4 is required for AP5}

suppression but not PTX induction of a set of genes

Because HDAC4 is a known transcriptional repressor (Haberland et al., 2009; Sando et al., 2012), we hypothesized that HDAC4 contributes to the altered gene expression pattern induced by AP5 treatment of cultured neurons. To address this, gene expression changes resulting from AP5 treatment were examined in the presence or absence of HDAC4. Infection of neurons with shH4_1-lentivirus suppressed HDAC4 mRNA (Fig. 5E, shH4_1 vehicle), confirming the efficacy of shH4_1 in neurons. Treatment of neurons with AP5 for $6 \mathrm{~h}$ resulted in a decrease in the expression of BDNF, HDAC5, NPAS4, Nr4a2, Nr4a3, and Ptgs2 (Fig. 5E). However, in neuronal cultures infected with shH4_1-lentivirus, AP5 had no effect on HDAC5 expression and had a significantly weaker effect on the suppression of BDNF, Nr4a2, and Ptgs2 (Fig. 5E, black bars). shH4_1lentivirus did not affect the AP5-induced decrease in expression of NPAS4 or Nr4a3; nor did it alter the basal expression of any of the genes examined here (Fig. $5 E$ ). The induction of BDNF, NPAS4, Nr4a2, Nr4a3, and Ptgs2 mRNAs by PTX was

A

\section{B}

C SEM. Student's $t$ test. shH4 1 untransfected

shH4 1 transfected
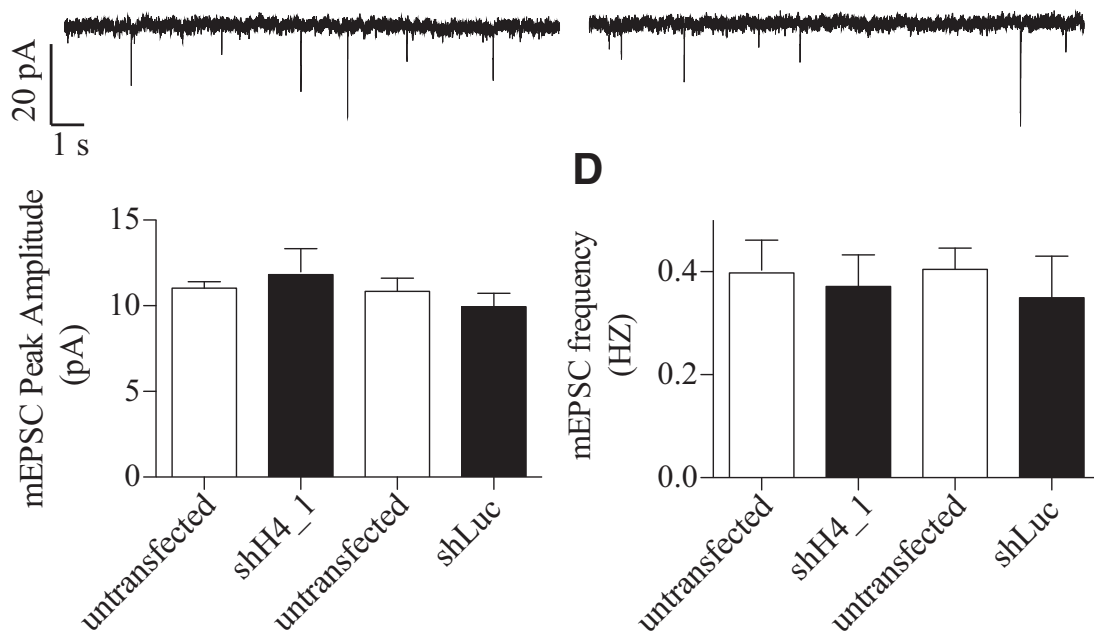

Figure 6. No effect of HDAC4 knockdown on mEPSCS. $\boldsymbol{A}, \boldsymbol{B}$, Sample traces of AMPA-mEPSCs recordings from shH4_1- or shLucexpressing CA1 pyramidal neurons and their adjacent untransfected neurons in DIV 7 to DIV 10 organotypic rat hippocampal slice cultures. $C, D$, Quantitation of average $m E P S C$ frequency and amplitude. Ten to 15 neurons were recorded from each condition. Error bars indicate the 
A
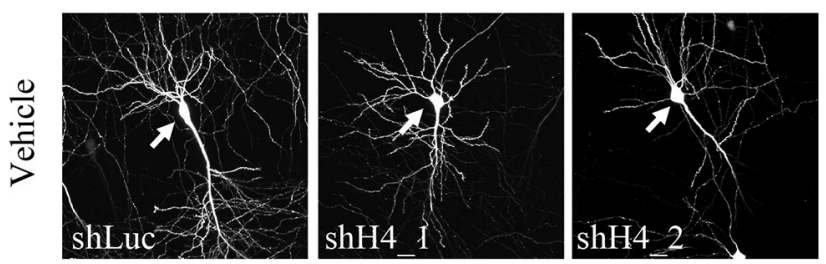

B
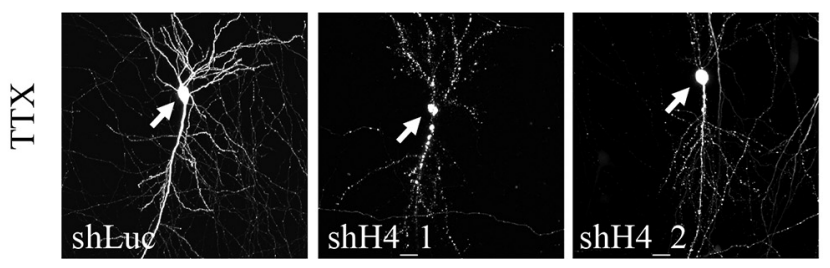

C

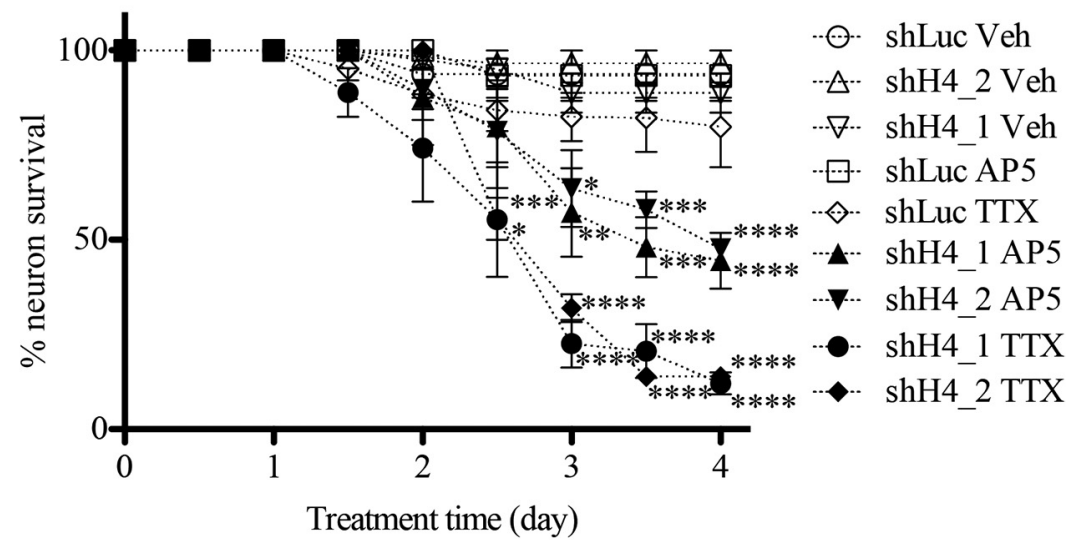

D

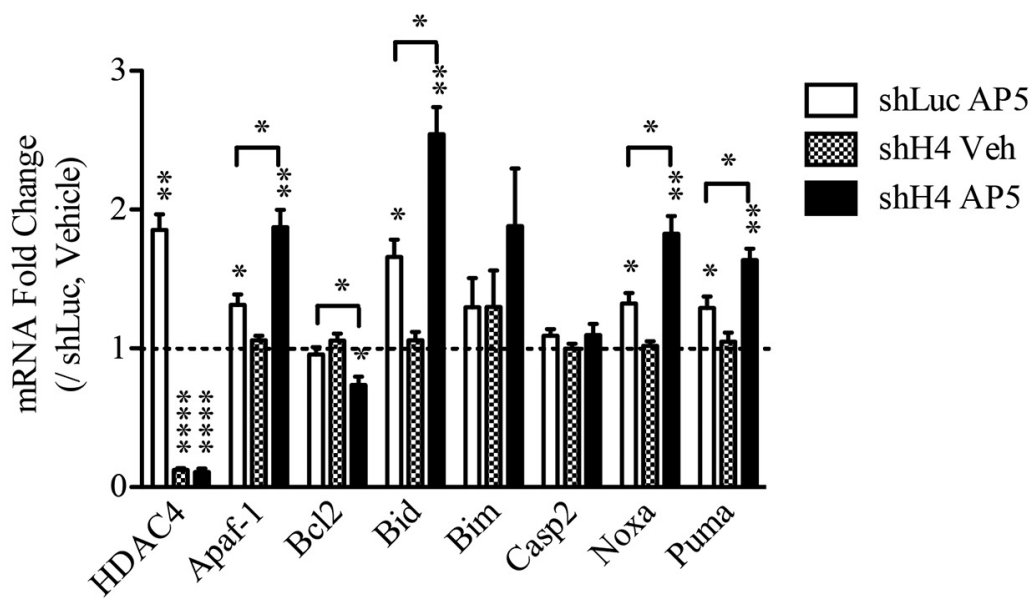

Figure 7. $\mathrm{HDAC} 4$ is neuroprotective and suppresses the expression of apoptosis-related genes under conditions of low NMDAR activity. $\boldsymbol{A}, \boldsymbol{B}$, Sample images of CA1 pyramidal neurons in hippocampal slice cultures expressing shLuc, shH4_1, or shH4_2 after treatment for $3 \mathrm{~d}$ with vehicle $(\boldsymbol{A})$ or TTX $(\boldsymbol{B})$. White arrows indicate cell bodies. $\boldsymbol{C}$, Percentage survival of CA1 pyramidal neurons transfected with shLuc, shH4_1, or shH4_2 after vehicle, AP5, or TTX treatment for the indicated times. $D$, Changes in mRNA levels of a panel of apoptosis-related genes were measured after AP5 (100 $\mu \mathrm{m})$ treatment for $6 \mathrm{~h}$ from lentivirus (shLuc or shH4)-infected dissociated hippocampal neurons. The fold change is normalized to vehicle. GAPDH was used as an internal control to normalize the mRNA level of each gene. Error bars indicate the SEM. ${ }^{*} p<0.05,{ }^{* *} p<0.01,{ }^{* * *} p<0.001,{ }^{* * *} p<0.0001$, tw0-way ANOVA. $n=4-5$ independent experiments.

\section{HDAC4 is required for neuronal survival under low NMDAR activity}

HDAC4 was shown to function as a transcriptional repressor and to play a role in regulating excitatory synapses (Haberland et al., 2009; Kim et al., 2012; Sando et al., 2012). Therefore, we tested whether HDAC4 knockdown altered excitatory synaptic transmission. In pyramidal neurons of organotypic hippocampal slice cultures, the expression of shH4_1 for $5 \mathrm{~d}$ did not alter the frequency or amplitude of mEPSCs, compared with either neighboring untransfected neurons or neurons expressing control shLuc (Fig. 6A-C). These data are consistent with a previous report (Kim et al., 2012) and argue that, at least under basal conditions, endogenous HDAC4, which is largely absent from the nucleus in these circumstances, has little effect on excitatory synaptic function.

Because HDAC4 most likely functions in the nucleus (Fig. 5; Haberland et al., 2009), and HDAC4 is induced and redistributed to nuclei when NMDAR activity is inhibited, we next studied the effects of HDAC4 knockdown in neurons treated with TTX or AP5. Neurons expressing shH4_1 or shH4_2 appeared similar to neurons expressing shLuc under basal conditions (Fig. $7 \mathrm{~A}, \mathrm{C}$, vehicle). However, $\sim 20 \%$ of shH4_1-transfected neurons disappeared after $2 \mathrm{~d}$ of TTX treatment, and $\sim 80 \%$ of the shH4_1-transfected neurons were either fragmented or disappeared after $3 \mathrm{~d}$ of TTX treatment (Fig. 7B, examples of healthy looking shLuc transfected neurons and fragmented shH4_1 or shH4_2 transfected neurons after 3 d TTX treatment). In contrast, control shLuctransfected neurons showed much better survival: $\sim 80 \%$ remained alive after up to $4 \mathrm{~d}$ of TTX treatment (Fig. $7 \mathrm{~B}, \mathrm{C}$ ). More than $90 \%$ of shH4_1- and shLuc-transfected neurons remained alive for up to $4 \mathrm{~d}$ in control basal conditions (vehicle treatment; Fig. 7C). Like TTX, AP5 caused a significant, albeit less severe, death of neurons transfected with shH4_1 (Fig. 7C). Similar results were obtained with a different HDAC4 shRNA (shH4_2; Fig. $7 \mathrm{~B}, \mathrm{C})$. These findings indicate that HDAC4 is required for neuronal survival under conditions of chronic low neuronal activity (TTX) or absence of basal NMDAR activity (AP5).

To investigate the underlying mechanism of the neuroprotective role of HDAC4, we measured the effect of HDAC4 knockdown on mRNA expression of apoptosisrelated genes in neurons after AP5 or vehicle treatment. Consistent with the microarray data, AP5 treatment significantly enhanced the expression of Apaf1, Bid, Noxa, and Puma in control shLucexpressing neurons (Fig. 7D). Knockdown of HDAC4 did not
alter the baseline expression of these apoptosis-related genes ("shH4 Veh"), but it caused a greater increase in their expression following AP5 treatment (Fig. 7D, compare "shH4 AP5," "shLuc AP5"). This suggests that HDAC4 is required to suppress expression of these apoptosis-related genes when NMDAR activity is blocked by AP5, likely contributing to its neuroprotective effects. 


\section{Discussion}

It is widely believed that activity-driven gene expression programs underlie long-term structural and functional changes in neurons (Flavell and Greenberg, 2008; Loebrich and Nedivi, 2009). However, it is not well understood how neuronal gene expression patterns are maintained under conditions of basal activity, where NMDARs are known to function (Sutton et al., 2006; Autry et al., 2011). In this study, we took a systematic genomewide approach to investigate the neuronal gene expression program regulated by NMDRs under conditions of basal activity.

We show that inhibition of basal NMDAR signaling by AP5 caused robust changes to numerous mRNAs, indicating that NMDARs actively regulate baseline neuronal gene expression. Surprisingly, the majority of genes strongly altered by AP5 in basal conditions were not significantly altered by bicucullineinduced NMDAR activity (Fig. $2 D, E$ ), suggesting that NMDARs control overlapping but distinct sets of genes in basal versus activating conditions. So, presumably different mechanisms regulate gene expression downstream of basal activity or bicucullineinduced stimulation of NMDARs. While basal synaptic activity encompasses both action potentials and spontaneous presynaptic release (Chawla et al., 2003; Sutton et al., 2006), bicuculline largely stimulates action potential bursting (Zhang et al., 2007). It has been suggested that spontaneous presynaptic release activates a separate pool of NMDARs with unique physiological functions compared with NMDARs activated via action potential-induced synaptic transmission (Sutton et al., 2006; Atasoy et al., 2008). It is possible that these two types of NMDAR activation recruit different downstream signaling mechanisms to regulate gene expression.

HDAC4 can function as a transcriptional repressor, shuttling between the cytosol and nucleus in response to neuronal activity (Zhao et al., 2001; Chawla et al., 2003; Haberland et al., 2009). While HDAC4 is required for neuronal function and has been implicated in a number of brain diseases (Bolger and Yao, 2005; Haberland et al., 2009; Williams et al., 2010; Kim et al., 2012; Li et al., 2012; Sando et al., 2012; Mielcarek et al., 2013), its molecular function in neurons remains unclear. Our data show that HDAC4 plays an important role in the repression of genes downstream of basal NMDAR signaling. Blockade of basal NMDAR activity by AP5 resulted in an increase in HDAC4 mRNA and protein levels, and subsequent redistribution of the HDAC4 protein to the nucleus. Further, HDAC4 was required, at least in part, for AP5-mediated repression of several genes including BDNF, HDAC5, Nr4a2, and Ptgs2. It is interesting to note that these same genes are transcriptionally upregulated after NMDAR activation via PTX. However, in contrast to their repression, the upregulation of these genes is independent of HDAC4. Thus, different mechanisms likely exist downstream of NMDARs to activate or repress the same target genes.

Previous reports found that synaptic NMDAR activity is negatively coupled to the expression of four genes involved in apoptosis, Apaf1, Puma, Casp3, and Casp9, using a different NMDAR antagonist, MK801 (Lau and Bading, 2009; Léveillé et al., 2010). Using an unbiased microarray approach, we find that, in addition to these four genes, basal NMDAR activity controls the expression of six other apoptosis-related genes. NMDAR-regulated genes were significantly enriched in the intrinsic apoptosis pathway, which suggests a link between basal NMDAR activity and apoptosis signaling.

The mRNA changes of the apoptosis-related genes were generally consistent with an enhancement of proapoptotic signaling by AP5: seven proapoptotic genes were induced (Apaf1, Bid, Bim, Casp2, Hrk, Noxa, and Puma), and one antiapoptotic gene was suppressed $(\mathrm{Bcl} 2)$. Four of these mRNA changes were also veri- fied to be significant in rat cultures with qRT-PCR (Fig. 7D); whereas, changes in Bim, Casp2, and Bcl2 did not reach significance, suggesting that these changes were not robust. Nonetheless, our cultures appeared healthy up to 1 week after continuous exposure to AP5, implying that these mRNA changes are not sufficient to cause neuronal death during this time frame (Fig. $3 D, E)$. The functional significance of the altered expression of apoptotic pathway components induced by AP5 remains to be addressed. Why do not the neurons die when NMDARs are blocked by AP5? Our study suggests a possibility that another gene expression program is induced simultaneously to protect neurons from apoptotic stress. One such mediator of this program is likely HDAC4, which was induced and entered the nucleus in the presence of AP5. Neurons deficient in HDAC4 were more vulnerable to cell death when NMDARs were blocked.

Our results suggest that the nuclear localization of HDAC4 induced by low NMDAR activity serves a neuroprotective role, perhaps through suppression of a set of apoptosis-related genes (Fig. 7D). This could explain why the loss of HDAC4 leads to neuronal defects (Kim et al., 2012). Interestingly, HDAC4 has been shown to protect cerebellar neurons against apoptosis by suppressing abortive cell cycle progression (Majdzadeh et al., 2008). The relationship between these two neuroprotective mechanisms of HDAC4 remains to be tested. Further, expression of a nuclear localized HDAC4 mutant under normal activity could result in ectopic gene expression changes, leading to neuronal defects through, for example, the chronic suppression of synapse-related genes (Sando et al., 2012).

We noticed that several genes that were regulated by AP5 in WT neurons were no longer responsive to AP5 in GluN2A KO neuronal cultures (e.g., Bid, DUSP6, icosl, and Plk3; Fig. 3B). These genes likely represent targets that are regulated by GluN2Acontaining NMDARs, but not by GluN2B-containing NMDARs. Even more strikingly, GADD45B expression responds to AP5 in the opposite direction in GluN2A KO cultures (downregulated; Fig. $3 B$ ) compared with the response seen in WT cultures (upregulated; Fig. $3 A$ ). This suggests that the expression of some genes is selectively or even inversely controlled by GluN2B or GluN2A containing diheteromeric NMDARs. The baseline expression of Bid, DUSP6, Plk3, UPF2, and GADD45B in GluN2A $\mathrm{KO}$ neuronal cultures was similar to their expression in WT cultures (Fig. 3C), which suggests that their differential response to AP5 in WT cultures versus GluN2A KO cultures is not caused by changes in their baseline expression.

In summary, we found that basal NMDAR activity governs a novel neuronal transcriptome and that HDAC4 contributes to this transcriptional regulation. Loss of HDAC4 promoted neuronal death in conditions of low NMDAR activity, highlighting a role for basal NMDAR signaling in neuronal survival that is partly dependent on HDAC4.

\section{References}

Atasoy D, Ertunc M, Moulder KL, Blackwell J, Chung C, Su J, Kavalali ET (2008) Spontaneous and evoked glutamate release activates two populations of NMDA receptors with limited overlap. J Neurosci 28:1015110166. CrossRef Medline

Auberson YP, Allgeier H, Bischoff S, Lingenhoehl K, Moretti R, Schmutz M (2002) 5-Phosphonomethylquinoxalinediones as competitive NMDA receptor antagonists with a preference for the human $1 \mathrm{~A} / 2 \mathrm{~A}$, rather than 1A/2B receptor composition. Bioorg Med Chem Lett 12:1099-1102. CrossRef Medline

Autry AE, Adachi M, Nosyreva E, Na ES, Los MF, Cheng PF, Kavalali ET, Monteggia LM (2011) NMDA receptor blockade at rest triggers rapid behavioural antidepressant responses. Nature 475:91-95. CrossRef Medline 
Benjamini Y, Yosef H (1995) Controlling the false discovery rate: a practical and powerful approach to multiple testing. J R Stat Soc Ser B 57:289-300.

Bolger TA, Yao TP (2005) Intracellular trafficking of histone deacetylase 4 regulates neuronal cell death. J Neurosci 25:9544-9553. CrossRef Medline

Bourgon R, Gentleman R, Huber W (2010) Independent filtering increases detection power for high-throughput experiments. Proc Natl Acad Sci U S A 107:9546-9551. CrossRef Medline

Brummelkamp TR, Bernards R, Agami R (2002) A system for stable expression of short interfering RNAs in mammalian cells. Science 296:550-553. CrossRef Medline

Chawla S, Vanhoutte P, Arnold FJ, Huang CL, Bading H (2003) Neuronal activity-dependent nucleocytoplasmic shuttling of HDAC4 and HDAC5. J Neurochem 85:151-159. CrossRef Medline

Darcy MJ, Calvin K, Cavnar K, Ouimet CC (2010) Regional and subcellular distribution of HDAC4 in mouse brain. J Comp Neurol 518:722-740. CrossRef Medline

Fischer G, Mutel V, Trube G, Malherbe P, Kew JN, Mohacsi E, Heitz MP, Kemp JA (1997) Ro 25-6981, a highly potent and selective blocker of $\mathrm{N}$-methyl-D-aspartate receptors containing the NR2B subunit. Characterization in vitro. J Pharmacol Exp Ther 283:1285-1292. Medline

Flavell SW, Greenberg ME (2008) Signaling mechanisms linking neuronal activity to gene expression and plasticity of the nervous system. Annu Rev Neurosci 31:563-590. CrossRef Medline

Haberland M, Montgomery RL, Olson EN (2009) The many roles of histone deacetylases in development and physiology: implications for disease and therapy. Nat Rev Genet 10:32-42. CrossRef Medline

Hagenston AM, Bading H (2011) Calcium signaling in synapse-to-nucleus communication. Cold Spring Harb Perspect Biol 3:a004564. CrossRef Medline

Hardingham GE, Bading H (2010) Synaptic versus extrasynaptic NMDA receptor signalling: implications for neurodegenerative disorders. Nat Rev Neurosci 11:682-696. CrossRef Medline

Hardingham GE, Fukunaga Y, Bading H (2002) Extrasynaptic NMDARs oppose synaptic NMDARs by triggering CREB shut-off and cell death pathways. Nat Neurosci 5:405-414. CrossRef Medline

Ivanov A, Pellegrino C, Rama S, Dumalska I, Salyha Y, Ben-Ari Y, Medina I (2006) Opposing role of synaptic and extrasynaptic NMDA receptors in regulation of the extracellular signal-regulated kinases (ERK) activity in cultured rat hippocampal neurons. J Physiol 572:789-798. CrossRef Medline

Jiao S, Li Z (2011) Nonapoptotic function of BAD and BAX in long-term depression of synaptic transmission. Neuron 70:758-772. CrossRef Medline

Kadotani H, Hirano T, Masugi M, Nakamura K, Nakao K, Katsuki M, Nakanishi S (1996) Motor discoordination results from combined gene disruption of the NMDA receptor NR2A and NR2C subunits, but not from single disruption of the NR2A or NR2C subunit. J Neurosci 16:7859-7867. Medline

Kessels HW, Nabavi S, Malinow R (2013) Metabotropic NMDA receptor function is required for beta-amyloid-induced synaptic depression. Proc Natl Acad Sci U S A 110:4033-4038. CrossRef Medline

Kim MJ, Dunah AW, Wang YT, Sheng M (2005) Differential roles of NR2Aand NR2B-containing NMDA receptors in Ras-ERK signaling and AMPA receptor trafficking. Neuron 46:745-760. CrossRef Medline

Kim MJ, Futai K, Jo J, Hayashi Y, Cho K, Sheng M (2007) Synaptic accumulation of PSD-95 and synaptic function regulated by phosphorylation of serine-295 of PSD-95. Neuron 56:488 -502. CrossRef Medline

Kim MS, Akhtar MW, Adachi M, Mahgoub M, Bassel-Duby R, Kavalali ET, Olson EN, Monteggia LM (2012) An essential role for histone deacetylase 4 in synaptic plasticity and memory formation. J Neurosci 32:1087910886. CrossRef Medline

Lau D, Bading H (2009) Synaptic activity-mediated suppression of p53 and induction of nuclear calcium-regulated neuroprotective genes promote survival through inhibition of mitochondrial permeability transition. J Neurosci 29:4420-4429. CrossRef Medline

Léveillé F, Papadia S, Fricker M, Bell KF, Soriano FX, Martel MA, Puddifoot C, Habel M, Wyllie DJ, Ikonomidou C, Tolkovsky AM, Hardingham GE (2010) Suppression of the intrinsic apoptosis pathway by synaptic activity. J Neurosci 30:2623-2635. CrossRef Medline

Li J, Chen J, Ricupero CL, Hart RP, Schwartz MS, Kusnecov A, Herrup K (2012) Nuclear accumulation of HDAC4 in ATM deficiency promotes neurodegeneration in ataxia telangiectasia. Nat Med 18:783-790. CrossRef Medline

Liu L, Wong TP, Pozza MF, Lingenhoehl K, Wang Y, Sheng M, Auberson YP, Wang YT (2004) Role of NMDA receptor subtypes in governing the direction of hippocampal synaptic plasticity. Science 304:1021-1024. CrossRef Medline

Loebrich S, Nedivi E (2009) The function of activity-regulated genes in the nervous system. Physiol Rev 89:1079-1103. CrossRef Medline

Lois C, Hong EJ, Pease S, Brown EJ, Baltimore D (2002) Germline transmission and tissue-specific expression of transgenes delivered by lentiviral vectors. Science 295:868-872. CrossRef Medline

Majdzadeh N, Wang L, Morrison BE, Bassel-Duby R, Olson EN, D’Mello SR (2008) HDAC4 inhibits cell-cycle progression and protects neurons from cell death. Dev Neurobiol 68:1076-1092. CrossRef Medline

Mielcarek M, Landles C, Weiss A, Bradaia A, Seredenina T, Inuabasi L, Osborne GF, Wadel K, Touller C, Butler R, Robertson J, Franklin SA, Smith DL, Park L, Marks PA, Wanker EE, Olson EN, Luthi-Carter R, van der Putten H, Beaumont V, et al. (2013) HDAC4 reduction: a novel therapeutic strategy to target cytoplasmic huntingtin and ameliorate neurodegeneration. PLoS Biol 11:e1001717. CrossRef Medline

Nakagawa T, Futai K, Lashuel HA, Lo I, Okamoto K, Walz T, Hayashi Y, Sheng M (2004) Quaternary structure, protein dynamics, and synaptic function of SAP97 controlled by L27 domain interactions. Neuron 44: 453-467. CrossRef Medline

Nelson CD, Kim MJ, Hsin H, Chen Y, Sheng M (2013) Phosphorylation of threonine- 19 of PSD- 95 by GSK-3 $\beta$ is required for PSD-95 mobilization and long-term depression. J Neurosci 33:12122-12135. CrossRef Medline

Neyton J, Paoletti P (2006) Relating NMDA receptor function to receptor subunit composition: limitations of the pharmacological approach. J Neurosci 26:1331-1333. CrossRef Medline

Paoletti P, Bellone C, Zhou Q (2013) NMDA receptor subunit diversity: impact on receptor properties, synaptic plasticity and disease. Nat Rev Neurosci 14:383-400. CrossRef Medline

Reisberg B, Doody R, Stöffler A, Schmitt F, Ferris S, Möbius HJ (2003) Memantine in moderate-to-severe Alzheimer's disease. N Engl J Med 348: 1333-1341. CrossRef Medline

Sala C, Rudolph-Correia S, Sheng M (2000) Developmentally regulated NMDA receptor-dependent dephosphorylation of cAMP response element-binding protein (CREB) in hippocampal neurons. J Neurosci 20:3529-3536. Medline

Sando R 3rd, Gounko N, Pieraut S, Liao L, Yates J 3rd, Maximov A (2012) HDAC4 governs a transcriptional program essential for synaptic plasticity and memory. Cell 151:821-834. CrossRef Medline

Shankar GM, Li S, Mehta TH, Garcia-Munoz A, Shepardson NE, Smith I, Brett FM, Farrell MA, Rowan MJ, Lemere CA, Regan CM, Walsh DM, Sabatini BL, Selkoe DJ (2008) Amyloid-beta protein dimers isolated directly from Alzheimer's brains impair synaptic plasticity and memory. Nat Med 14:837-842. CrossRef Medline

Sutton MA, Ito HT, Cressy P, Kempf C, Woo JC, Schuman EM (2006) Miniature neurotransmission stabilizes synaptic function via tonic suppression of local dendritic protein synthesis. Cell 125:785-799. CrossRef Medline

Taylor RC, Cullen SP, Martin SJ (2008) Apoptosis: controlled demolition at the cellular level. Nat Rev Mol Cell Biol 9:231-241. CrossRef Medline

Wei W, Nguyen LN, Kessels HW, Hagiwara H, Sisodia S, Malinow R (2010) Amyloid beta from axons and dendrites reduces local spine number and plasticity. Nat Neurosci 13:190-196. CrossRef Medline

Williams SR, Aldred MA, Der Kaloustian VM, Halal F, Gowans G, McLeod DR, Zondag S, Toriello HV, Magenis RE, Elsea SH (2010) Haploinsufficiency of HDAC4 causes brachydactyly mental retardation syndrome, with brachydactyly type E, developmental delays, and behavioral problems. Am J Hum Genet 87:219-228. CrossRef Medline

Zarate CA Jr, Singh JB, Carlson PJ, Brutsche NE, Ameli R, Luckenbaugh DA, Charney DS, Manji HK (2006) A randomized trial of an N-methyl-Daspartate antagonist in treatment-resistant major depression. Arch Gen Psychiatry 63:856-864. CrossRef Medline

Zhang SJ, Steijaert MN, Lau D, Schütz G, Delucinge-Vivier C, Descombes P, Bading H (2007) Decoding NMDA receptor signaling: identification of genomic programs specifying neuronal survival and death. Neuron 53: 549-562. CrossRef Medline

Zhao X, Ito A, Kane CD, Liao TS, Bolger TA, Lemrow SM, Means AR, Yao TP (2001) The modular nature of histone deacetylase HDAC4 confers phosphorylation-dependent intracellular trafficking. J Biol Chem 276: 35042-35048. CrossRef Medline

Zhou Q, Sheng M (2013) NMDA receptors in nervous system diseases. Neuropharmacology 74:69-75. CrossRef Medline 